
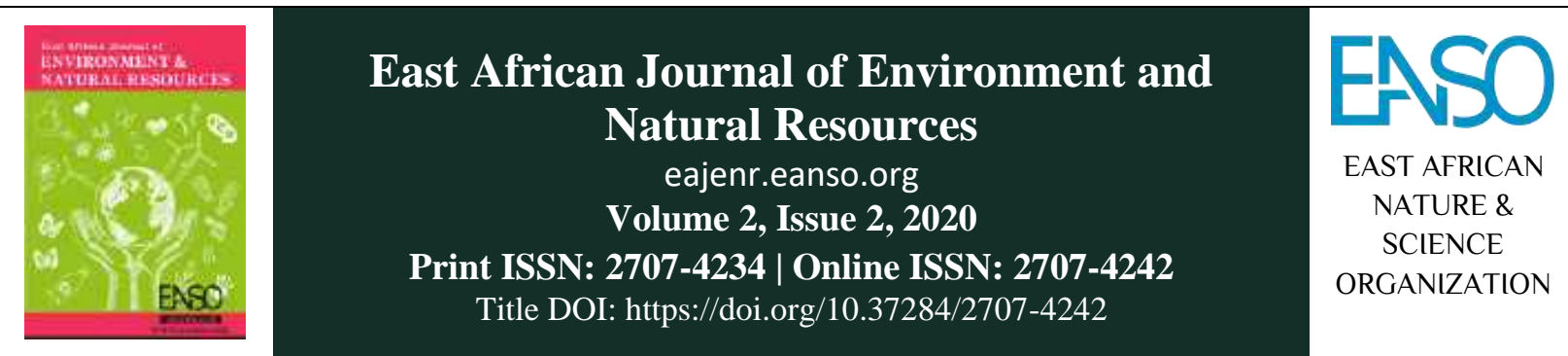

Original Article

\title{
Influence of Nairobi's Biophysical Characteristics on its Vulnerability to a Changing Climate
}

\author{
Sunday Julius Abuje ${ }^{1 *}$, Prof. Bernard Moirongo Otoki ${ }^{1} \&$ Dr. Bernard Mugwima Njuguna ${ }^{1}$ \\ ${ }^{1}$ Jomo Kenyatta University of Agriculture and Technology, P. O. Box 62000 - 00200 Nairobi, Kenya. \\ *Author for Correspondence email: sunabuje@sabs.jkuat.ac.ke \\ * ORCID: https://orcid.org/0000-0002-7601-827X
}

Article DOI: https://doi.org/10.37284/eajenr.2.2.201

\section{Date Published: ABSTRACT}

28 August 2020 Urban areas experience exacerbated impacts of the regional climate variability because of their form characteristics such as imperviousness of surfaces,

Keywords: building density and distribution of open spaces. These are further confounded

Vulnerability, Climate Change, Biophysical,

Nairobi, Adaptation. by geographical aspects such as topography, soil types, and vegetation types. Nairobi city is increasingly exposed to flood and heat risk as an aggregation of its urban form and the changing global climate. The paper sought to establish the influence of Nairobi's biophysical characteristics on its vulnerability to both flooding and heat risks. The paper used a descriptive research design augmented with Geographic Information Systems to spatially model the landcover, soil drainage, topography, green space networks, and population density characteristics at the sub-location level. Vulnerability indices were developed using the expert ranking system and used to determine the vulnerability of the different sub-locations. The findings revealed a vulnerability pattern close to the historically segregated planning of the city. The central and eastern parts of the city exhibit high vulnerability while the western, northwestern, and southern parts of the city display moderate to low vulnerability. The paper recommends that adapting existing neighbourhoods and proactive planning of new neighbourhoods uses the ecosystem-based approach. This to entail decentralization of smaller green spaces, redesign of road medians for water management, re-specification of street vegetation species to incorporate a mix of deciduous and evergreen trees and incorporating eco-roofs and walls in highdensity developments like the Central Business District. 
East African Journal of Environment and Natural Resources, Volume 2, Issue 2, 2020

Article DOI: https://doi.org/10.37284/eajenr.2.2.201

\section{APA CITATION}

Abuje, S., Otoki, B., \& Njuguna, B. (2020). Influence of Nairobi's Biophysical Characteristics on its Vulnerability to a Changing Climate. East African Journal of Environment and Natural Resources, 2(2), 64-85. https://doi.org/10.37284/eajenr.2.2.201

\section{CHICAGO CITATION}

Abuje, Sunday, Bernard Otoki, and Bernard Njuguna. 2020. "Influence of Nairobi's Biophysical Characteristics on its Vulnerability to a Changing Climate". East African Journal of Environment and Natural Resources 2 (2), $64-85$. https://doi.org/10.37284/eajenr.2.2.201

\section{HARVARD CITATION}

Abuje, S., Otoki, B. and Njuguna, B. (2020) “Influence of Nairobi's Biophysical Characteristics on its Vulnerability to a Changing Climate", East African Journal of Environment and Natural Resources, 2(2), pp. 64-85. doi: 10.37284/eajenr.2.2.201.

\section{IEEE CITATION}

S. Abuje, B. Otoki, and B. Njuguna, "Influence of Nairobi's Biophysical Characteristics on its Vulnerability to a Changing Climate", EAJENR, vol. 2, no. 2, pp. 64-85, Aug. 2020.

\section{MLA CITATION}

Abuje, Sunday, Bernard Otoki, and Bernard Njuguna. "Influence of Nairobi's Biophysical Characteristics on its Vulnerability to a Changing Climate". East African Journal of Environment and Natural Resources, Vol. 2, no. 2, August 2020, pp. 64-85, doi:10.37284/eajenr.2.2.201.

\section{INTRODUCTION}

\section{Global Climate and Biophysical Characteristics of Urban Areas}

Over $60 \%$ of the world's population is expected to be living in urban areas by the year 2050 (United Nations Department of Economic and Social Affairs, 2018). Similarly, the United Nations Framework Convention on Climate Change (UNFCCC) (2011) and World Meteorological Organization (WMO) (2019) projects that the impacts of climate change will be exacerbated the world over. As a result, the urban population is likely to experience confounded vulnerability. First, because of the increased incidences of climate-related hazards that affect the global environment (Thomas \& López, 2015). Second, from the urban biophysical characteristics that influence how climatic parameters interact with urban locales and inhabitants (Oke, Mills, Christen, \& Voogt, 2017).

The interaction between climatic factors and urban characteristics determines vulnerability at the urban level. Vulnerability in this context is the degree to which a system is susceptible to and unable to cope with adverse effects of climate change, including climate variability and extremes (Perry, Canziani, Palutikof, Linden, \& Hanson, 2007). Its main determinants are exposure, sensitivity, and adaptive capacity (Intergovernmental Panel on Climate
Change (IPCC), 2014; Krellenberg, Welz, Link, \& Barth, 2017; Satapathy et al., 2014).

Exposure is the presence of people; livelihoods; environmental services and resources; infrastructure; or economic, social, or cultural assets in places that could be adversely affected (Field, Barros, Stocker, \& Dahe, 2012; Fritzsche et al., 2014). Sensitivity is the degree to which a system is affected directly or indirectly, either adversely or beneficially, by climate-related stimuli (McCarthy, Canziani, Leary, Dokken, \& White, 2001). Adaptive capacity is the ability of a system to adjust to climate change, moderate potential impacts through the combination of the strengths, attributes, and resources available to an individual, community, society, or organization (Perry et al., 2007). The confluence of these determinants defined by equation 1 developed from Satapathy et al. (2014) shows their contribution to vulnerability. Exposure in this paper applies to climatic parameters, while sensitivity encompasses aspects of the biophysical characterization of the city.

$V=\sum_{k=1}^{n} w S+\sum_{k=1}^{n} w E-\sum_{k=1}^{n} w A \ldots \ldots \ldots[1]$

Where V: Vulnerability index; wS: Weighted indicators for climate change sensitivity; wE: Weighted indicators for climate exposure; wA: Weighted indicators for adaptive capacity,

Vulnerability assessment has been increasingly discussed in various aspects. However, the 
dominant approach within the context of climate change often looks at the biophysical and socioeconomic characteristics within the confines of exposure, sensitivity, and adaptive capacity. Several factors have been developed to aid in vulnerability assessment. The key biophysical factors of urban areas that influence how it interacts with climate and by extension vulnerability include soil hydro-lithology (Mentzafou, Markogianni, \& Dimitriou, 2018; Skilodimou, Bathrellos,
Chousianitis, Youssef, \& Pradhan, 2019), land use/ land cover: the ratio of built-up to open spaces (Dou et al., 2018; Gigović, Pamučar, Bajić, \& Drobnjak, 2017) and topography (Doyle, Sullivan, Mahtta, \& Pandey, 2017) and dwelling types (Table 1 and 2). For instance, soil and topography influence runoff, affecting vulnerability to floods. Dwelling types and density of built-up areas affect surface temperatures, influencing heat stress.

Table 1: Biophysical factors and indicators of flood vulnerability

\begin{tabular}{|c|c|c|}
\hline $\begin{array}{l}\text { Flood Risk } \\
\text { Factors }\end{array}$ & Indicators & Authors \\
\hline Elevation & $\begin{array}{l}\text { Height relative to } \\
\text { the lowest point in } \\
\text { the area }\end{array}$ & $\begin{array}{l}\text { Ouma \& Tateishi, 2014; Chen, Ito, Sawamukai, \& Tokunaga, } \\
\text { 2015; Bathrellos, Karymbalis, Skilodimou, Gaki- } \\
\text { Papanastassiou, \& Baltas, 2016; Gigovich, Pamvear, Bajic, \& } \\
\text { Drobnjak, 2017; Dou et al., 2017 and Skilodimou, Bathrellos, } \\
\text { Chousianitis, Youssef, \& Pradhan, } 2019 .\end{array}$ \\
\hline Slope & $\begin{array}{l}(\mathrm{L} / \mathrm{H})^{*} 100 \\
\text { L: Horizontal } \\
\text { distance } \\
\text { H: Vertical change } \\
\text { in height }\end{array}$ & $\begin{array}{l}\text { (Gigovich, Pamvear, Bajic, \& Drobnjak, 2017) (Bathrellos, } \\
\text { Karymbalis, Skilodimou, Gaki-Papanastassiou, \& Baltas, } \\
\text { 2016) (Ouma \& Tateishi, 2014) (Stefanidis \& Stathis, 2013) } \\
\text { (Dou, et al., 2017) (Doyle, Sullivan, Mahtta, \& Pandey, 2017) } \\
\text { (Skilodimou, Bathrellos, Chousianitis, Youssef, \& Pradhan, } \\
\text { 2019) (Mentzafou, Markgianni, \& Dimitriou, 2017) }\end{array}$ \\
\hline $\begin{array}{l}\text { Land } \\
\text { Cover/Use }\end{array}$ & $\begin{array}{l}\text { The type } \\
\text { (permeability and } \\
\text { roughness of land } \\
\text { cover) }\end{array}$ & $\begin{array}{l}\text { (Gigovich, Pamvear, Bajic, \& Drobnjak, 2017) (Bathrellos, } \\
\text { Karymbalis, Skilodimou, Gaki-Papanastassiou, \& Baltas, } \\
\text { 2016) (Ouma \& Tateishi, 2014) (Elkhrachy, 2015) (Stefanidis } \\
\text { \& Stathis, 2013) (Dou, et al., 2017) (Skilodimou, Bathrellos, } \\
\text { Chousianitis, Youssef, \& Pradhan, 2019) (Mentzafou, } \\
\text { Markgianni, \& Dimitriou, 2017) }\end{array}$ \\
\hline $\begin{array}{l}\text { Hydro- } \\
\text { lithology (Soil } \\
\text { and Geology) }\end{array}$ & $\begin{array}{l}\text { Geological } \\
\text { permeability } \\
\text { (Classified as } \\
\text { permeable; semi- } \\
\text { permeable and } \\
\text { impermeable) }\end{array}$ & $\begin{array}{l}\text { (Bathrellos, Karymbalis, Skilodimou, Gaki-Papanastassiou, \& } \\
\text { Baltas, 2016) (Ouma \& Tateishi, 2014) (Elkhrachy, 2015) } \\
\text { (Stefanidis \& Stathis, 2013) (Dou, et al., 2017) (Dou, et al., } \\
\text { 2017) (Chen, Ito, Sawamukai, \& Tokunaga, 2015) } \\
\text { (Skilodimou, Bathrellos, Chousianitis, Youssef, \& Pradhan, } \\
\text { 2019) (Mentzafou, Markgianni, \& Dimitriou, 2017) }\end{array}$ \\
\hline $\begin{array}{l}\text { Rainfall } \\
\text { Intensity }\end{array}$ & & $\begin{array}{l}\text { (Dou, et al., 2017) (Chen, Ito, Sawamukai, \& Tokunaga, 2015) } \\
\text { (Mentzafou, Markgianni, \& Dimitriou, 2017) }\end{array}$ \\
\hline $\begin{array}{l}\text { Flow } \\
\text { Accumulation }\end{array}$ & & $\begin{array}{l}\text { (Dou, et al., 2017) (Mentzafou, Markgianni, \& Dimitriou, } \\
\text { 2017) }\end{array}$ \\
\hline
\end{tabular}


East African Journal of Environment and Natural Resources, Volume 2, Issue 2, 2020

Article DOI: https://doi.org/10.37284/eajenr.2.2.201

Table 2: Biophysical factors and indicators of heat vulnerability

\begin{tabular}{|c|c|c|}
\hline $\begin{array}{l}\text { Heat Risk } \\
\text { Factors }\end{array}$ & Indicators & Authors \\
\hline Temperature & $\begin{array}{l}\text { Land Surface } \\
\text { Temperature } \\
\text { Air Temperature } \\
\text { No. of Hot Days } \\
\text { (above a certain value) } \\
\text { Daily Maximum } \\
\text { Daily Minimum }\end{array}$ & $\begin{array}{l}\text { (Inostroza, Palme, \& de la Barrera, 2016) (Bao, Li, \& Yu, } \\
\text { 2015) (Romero-Lankao, Qin, \& Dickinson, 2012) (Weber, } \\
\text { Sadoff, Zell, \& de Sherbinin, 2015) (Wolf \& McGregor, } \\
\text { 2013) (Swart, et al., 2012) (Mendez-Lazaro, Muller-Karger, } \\
\text { Otis, McCarthy, \& Rodriguez, 2017) (Mendez-Lazaro, } \\
\text { Muller-Karger, Otis, McCarthy, \& Rodriguez, 2017) } \\
\text { (Janicke, et al., 2018) (Dong, et al., 2014) (Macintyre, et al., } \\
\text { 2018) (Apreda, D'Ambrosio, \& Di Martino, 2019) }\end{array}$ \\
\hline Dwelling type & $\begin{array}{l}\text { Buildings Materials } \\
\text { (Roof and walls) }\end{array}$ & $\begin{array}{l}\text { (Inostroza, Palme, \& de la Barrera, 2016) (Bao, Li, \& Yu, } \\
\text { 2015) (Romero-Lankao, Qin, \& Dickinson, 2012) (Nayak, et } \\
\text { al., 2018) (Wolf \& McGregor, 2013) (Stangl, 2018) } \\
\text { (Macintyre, et al., 2018) }\end{array}$ \\
\hline $\begin{array}{l}\text { Normalized } \\
\text { Differential } \\
\text { Vegetation } \\
\text { Index (NDVI) }\end{array}$ & $\begin{array}{l}\text { Plantings/Vegetation } \\
\text { Parks }\end{array}$ & $\begin{array}{l}\text { (Inostroza, Palme, \& de la Barrera, 2016) (Pincetl, Chester, } \\
\& \text { Eisenman, 2016) (Weber, Sadoff, Zell, \& de Sherbinin, } \\
\text { 2015) (Swart, et al., 2012) (Barron, Ruggieri, \& Branas, } \\
\text { 2018) (Stangl, 2018) (Apreda, D'Ambrosio, \& Di Martino, } \\
\text { 2019) }\end{array}$ \\
\hline $\begin{array}{l}\text { Urban } \\
\text { Morphology/ } \\
\text { LU/LC }\end{array}$ & $\%$ of LU/LC & $\begin{array}{l}\text { (Pincetl, Chester, \& Eisenman, 2016) (Wilhelmi \& Hayden, } \\
\text { 2010) (Reid, et al., 2009) (Romero-Lankao, Qin, \& } \\
\text { Dickinson, 2012) (Nayak, et al., 2018) (Wolf \& McGregor, } \\
\text { 2013) (Wolf \& McGregor, 2013) (Mendez-Lazaro, Muller- } \\
\text { Karger, Otis, McCarthy, \& Rodriguez, 2017) (Stangl, 2018) } \\
\text { (Savic, et al., 2018) }\end{array}$ \\
\hline $\begin{array}{l}\text { Population } \\
\text { Density }\end{array}$ & $\%$ population per $\mathrm{Km}^{2}$ & $\begin{array}{l}\text { (Bao, Li, \& Yu, 2015) (Romero-Lankao, Qin, \& Dickinson, } \\
\text { 2012) (Nayak, et al., 2018) (Wolf \& McGregor, 2013) (Swart, } \\
\text { et al., 2012) (Gamble, et al., 2018) (Dong, et al., 2014) }\end{array}$ \\
\hline
\end{tabular}

\section{NAIROBI CITY'S CLIMATE AND BIOPHYSICAL CHARACTER}

This paper is based on Nairobi as defined by the city-county boundary comprising the 112 sublocations as at the 2008 housing and population census (Figure 1). Nairobi referred to as a citycounty since the entire city is a county. It extends between $36^{\circ} 4^{\prime}$ and $37^{\circ} 10^{\prime}$ East and between $1^{\circ} 9^{\prime}$ and $1^{\circ} 28^{\prime}$ south. The city has a population of about 4.7 million people within an area of about $695 \mathrm{~km}^{2}$ as per the 2019 Kenya National Bureau of Statistics
(KNBS, 2019). The city has 112 sub-locations with varying population densities. High-income sublocations have average densities as low as 500 people $/ \mathrm{km}^{2}$ while low-income locations such as those in the informal settlements have densities as high as 63000 people $/ \mathrm{km}^{2}$. 
Figure 1: Nairobi city-county boundary showing sub-locations

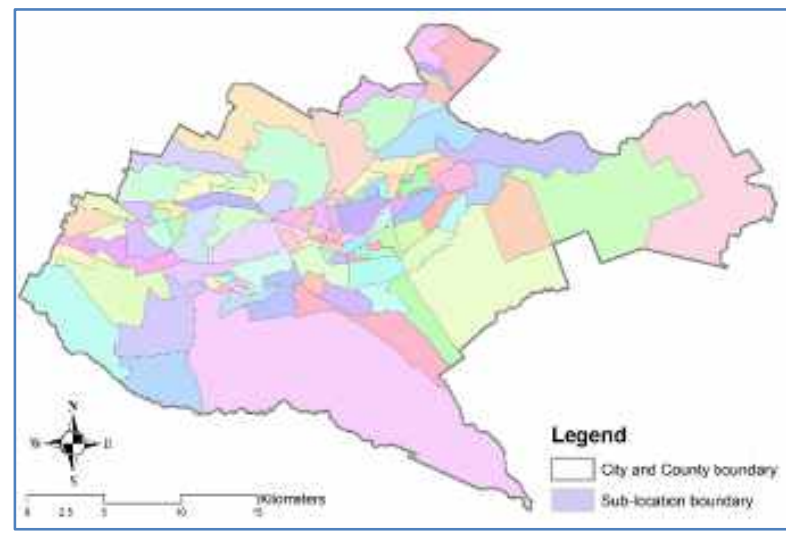

Nairobi has an undulating topography with an elevation range of $1,460 \mathrm{~m}-1,920 \mathrm{~m}$ above sea level. The lowest elevation occurs at Athi River at the eastern boundary of the city and highest at the western rim of the city. Average annual rainfall in Nairobi is about $900 \mathrm{~mm}$ with peaks in April and November (Figure 2). The mean daily maximum temperature by month ranges from $28{ }^{\circ} \mathrm{C}$ to $22{ }^{\circ} \mathrm{C}$ and the minimum ranges from $14^{\circ} \mathrm{C}$ to $12^{\circ} \mathrm{C}$ (Japan International Cooperation Agency (JICA), 2004). Nairobi is underlain by tertiary volcanic rocks and the soil types are the grey clays, black clays, red clays, reddish-brown clays and brown clays with varying soil drainage properties (University of Nairobi, 2018).

Figure 2: Nairobi's climate profile

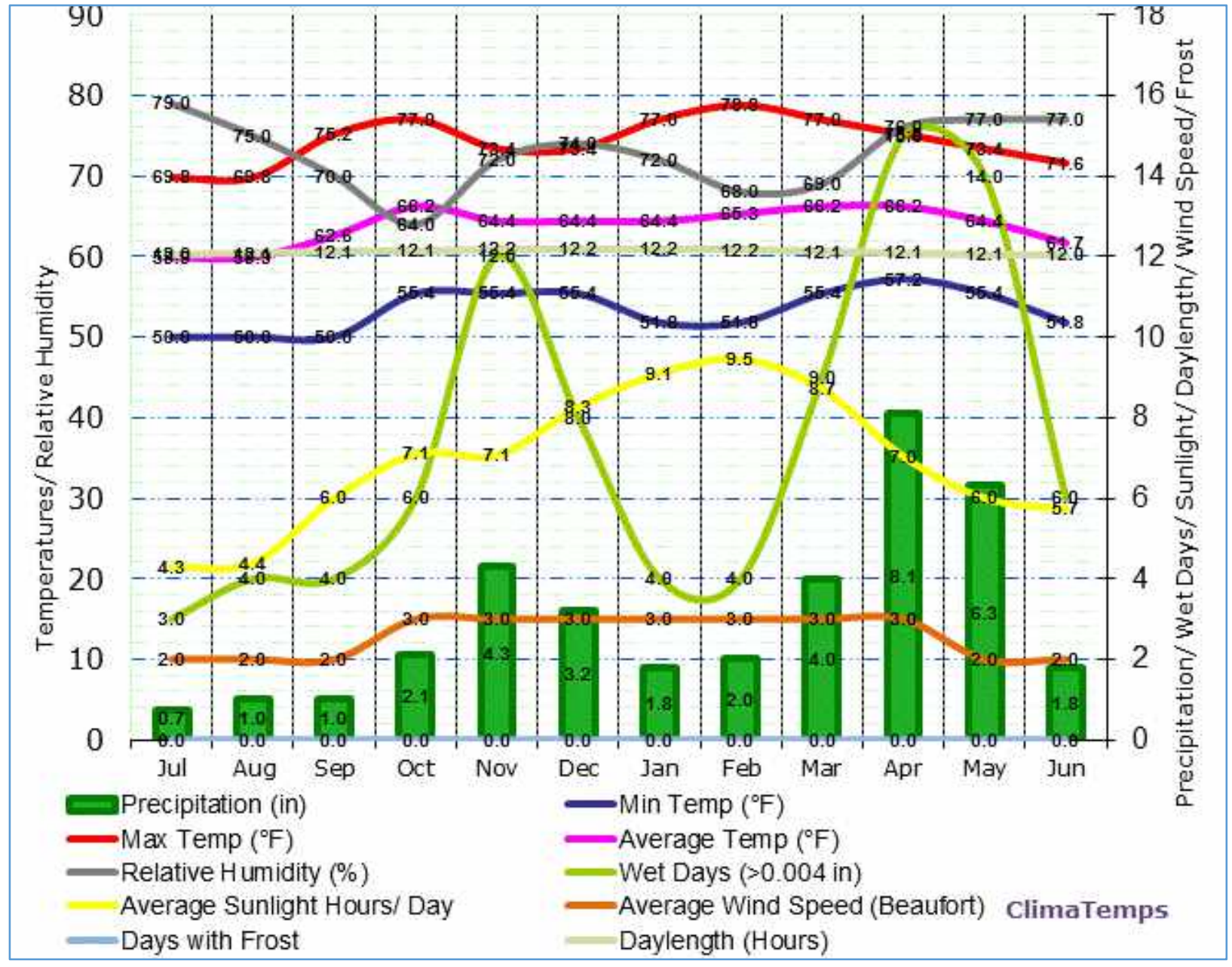

Source: (http://www.nairobi.climatemps.com/graph.php) 


\section{METHOD}

\section{Procedure for Data collection and analysis}

The paper used a descriptive approach and modelling of the parameters in ArcMap 10.6. The modelling developed thematic maps of the biophysical parameters. Heat and flood vulnerability mapping followed this. Vulnerability mapping was based on an aggregation of the experts' ranking of parameters. The ranking determined their contribution to vulnerability within the classes of sensitivity and exposure. The census data further aided in developing population density maps. Even though population density is a socio-economic parameter, it was selected to represent density data since the landcover images only show the 2-dimensional density.

The biophysical data comprised Landsat images, Digital Elevation Models (DEMs) and Soil data. The topography, flow accumulation and landcover were modelled from Landsat and DEMs. Kenya
Agriculture and Livestock Research Organization (KALRO) and Survey of Kenya (SoK) supplied soil data. Kenya Meteorological Department (KMD) and the IGAD Climate Prediction and Applications Center (ICPAC) supplied the climatic data.

The landcover data underwent pre-processing and post-image processing to enhance the output of the images in terms of quality by correcting any image distortions. The satellite imagery was geometrically corrected and projected to ARC 1960 Universal Traverse Mercator (UTM) $37 \mathrm{~S}$; a recognized projected co-ordinate system in Kenya. A pixelbased hybrid classification method was adopted. It combined supervised and unsupervised classification methods. The supervised method was adopted for its effectiveness and accuracy, while the unsupervised method was used to plug the gaps and minimize errors in the supervised method. The resultant images were then merged using the reclassify tool in ArcMap 10.6. The resultant landcover classes were built-up areas, forest, bare lands, grasslands, water bodies (Table 3)

Table 3: The landcover classes, their descriptions and used colour codes

\begin{tabular}{l|ll}
\hline LAND COVER & DESCRIPTION & $\begin{array}{l}\text { COLOUR } \\
\text { CODE }\end{array}$ \\
\hline BUILT-UP & $\begin{array}{l}\text { Urban fabric: temporary and permanent houses, artificial } \\
\text { infrastructure including paved streets }\end{array}$ & Red \\
FOREST & Areas with trees & Green \\
BARE LANDS & Exposed soils, landfill sites, and areas of active excavation & Brown \\
GRASSLANDS & Shrublands and grasslands & Yellow \\
WATERBODY & River, permanent open water, perennial lakes, reservoirs, ponds & Blue \\
\hline
\end{tabular}

The population density data was modelled from boundary and population data of the 2008 population and housing census. The land area computation was derived from the acreage of the sub-locations; generated in ArcMap 10.6 based on the sub-location shapefile. These outputs were used to determine the population density in MS Excel (Equation 2).

Population Density $=\frac{\text { Number of People }}{\text { Land Area }} \ldots \ldots . . .[2]$

The soil data parameter used was soil drainage properties. These were classified by International Soil Reference and Information Center (ISRIC) as excessively drained, somewhat excessively welldrained, moderately well-drained, imperfectly drained, poorly drained, very poorly drained and a non-classified section. The non-classified section is the built-up area. A thematic map based on the classifications found in Nairobi was developed.

Terrain data was modelled from the $2 \mathrm{~m}$ spatial resolution DEM using ArcMap 10.6. The DEM that was projected to Arc 1960 UTM zone 37S. The output was used to create a slope raster file. The slope classifications were $0 \%-4 \%, 4 \%-8 \%, 8 \%$ $12 \%, 12 \%-16 \%$ and $16 \%-100 \%$. The selection of the classifications was based on studies by Nassif \& Wilson (1975) and Huang, Kang, Yang, \& Jin (2017) who note those slopes as the ones that impact stormwater runoff. The terrain dataset was further used to develop Flow Accumulation Maps. 
Relying on the DEM, the spatial analyst tool in ArcMap was used to generate fill raster image which was then used to calculate the flow direction and develop the flow accumulation map.

The values of the parameters were normalized (eq. iii) as recommended by Swanson, Hiley, \& Venema (2007), Elmoustafa (2012) and Inostroza, Palme, \& de la Barrera (2016). This is to eliminate any misinterpretation that could result from the different units of measurements used. The normalized data were used to generate thematic vulnerability maps.

$X_{\text {nor }}=\frac{X-X_{\min }}{X_{\max }-X_{\min }}$

Where $\mathrm{X}_{\text {nor. }}$ - The normalized $\mathrm{X}$; $\mathrm{X}$-The values $\mathrm{X}_{1}$ $X_{n} ; X_{\min }$ - The lowest value of $X ; X_{\max }$ - The highest value of $X$

A vulnerability index was developed using the statistical mean. Vulnerability ranking used a fourlevel scale of Very High Vulnerability (VHV), High Vulnerability (HV), Moderate Vulnerability (MV) and Low Vulnerability (LV). From the vulnerability maps of the different parameters, the overall vulnerability of the county to heat and flood risks was computed. It was based on the expert rankings of the contributions of the unique aspects of heat and flood risks. The ranking was based on the Likert type scale (Figure 3). The paper considered 12 experts in the fields of architecture, urban planning, landscape architecture and hydrology.

Figure 3: Likert Scale for expert ranking of biophysical parameters

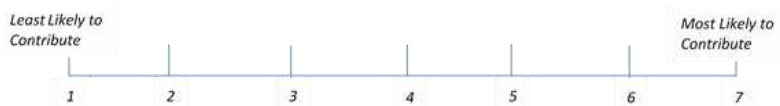

\section{Figure 4: Analytical framework}

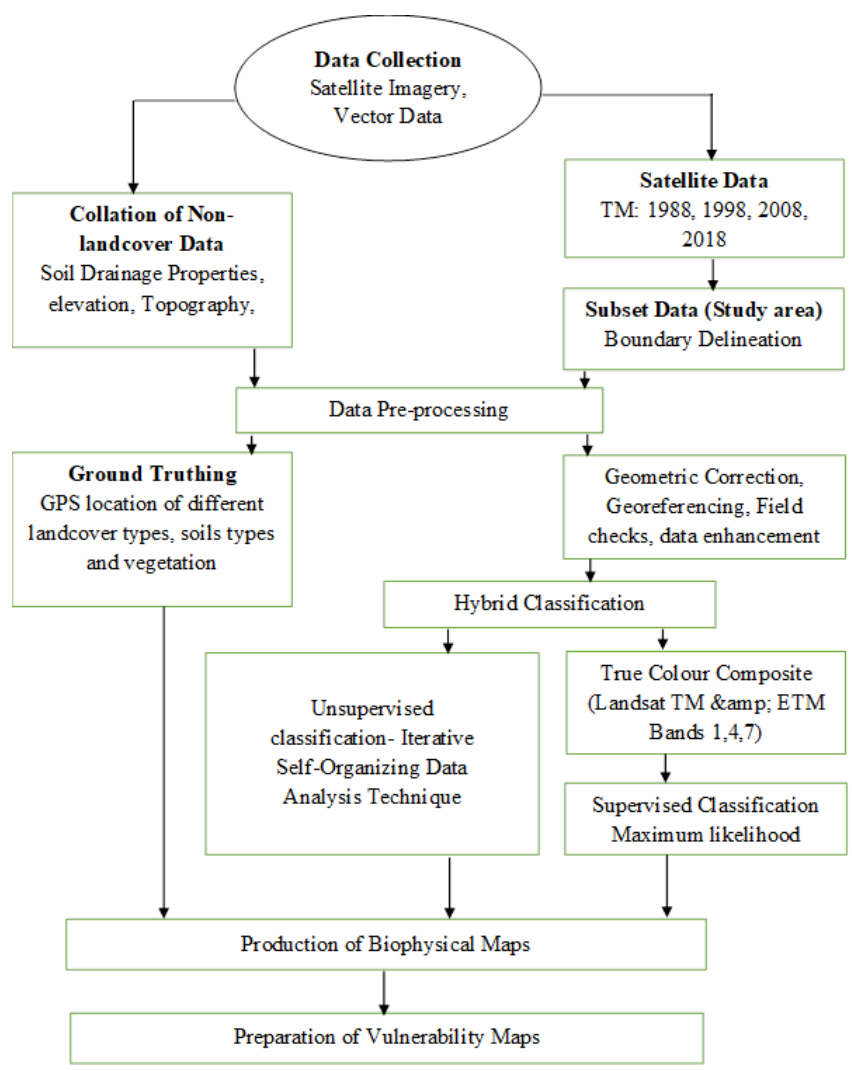

\section{RESULTS}

\section{Land use/Landcover}

Dominant land covers in the city are grassland at $244 \mathrm{~km}^{2}$ and built-up area at $228 \mathrm{Km}^{2}$ while the least land cover is a water body at $4 \mathrm{~km}^{2}$ (Figure 5). The built-up area encompasses buildings and paved surfaces such as roads. It is dominant in the central zone of the city, reducing towards the periphery. This translates to a Very High Vulnerability (VHV) to flooding and heat stress in the central zone (Figure 6). 
East African Journal of Environment and Natural Resources, Volume 2, Issue 2, 2020 Article DOI: https://doi.org/10.37284/eajenr.2.2.201

Figure 5: Nairobi's 2018 land cover classification

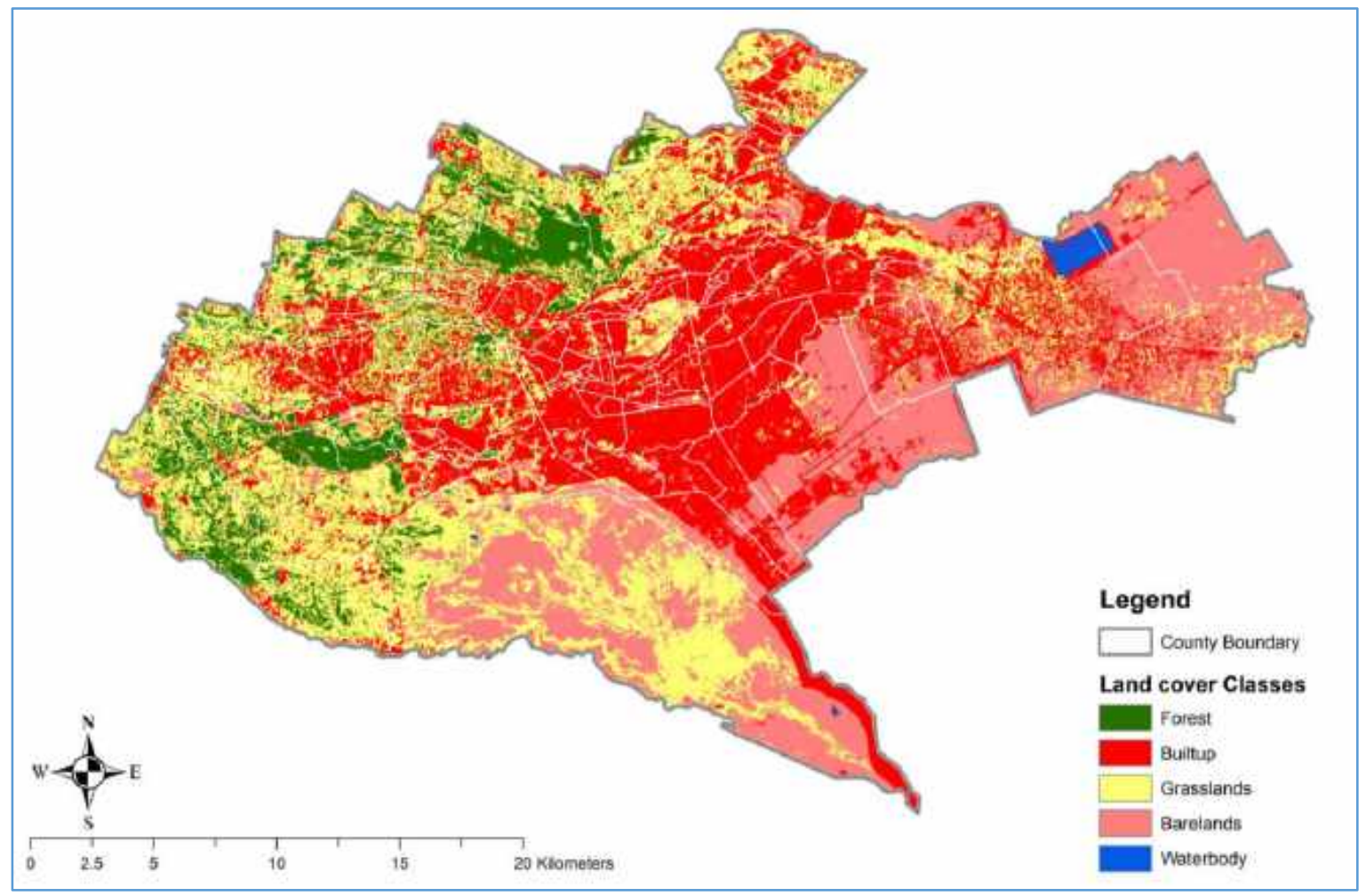

Figure 6: Nairobi city's flood and heat stress vulnerability map-based land cover

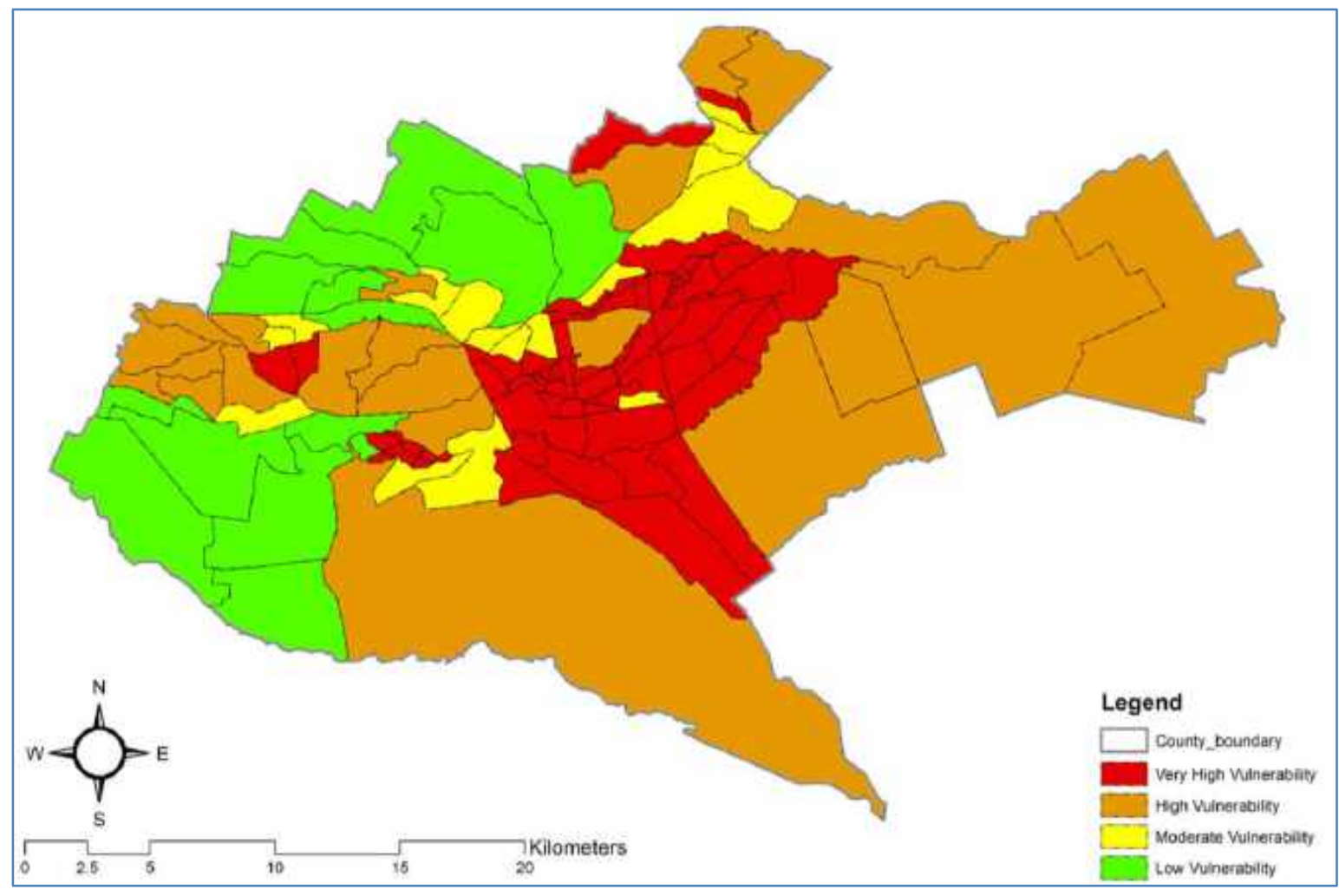




\section{Population Density}

The densest sub-locations with normalized densities above 0.6 include Lindi, Laini Saba, Kibra, Gatwikira, Korogocho, Mathare 4A and Uhuru (Figure 7). They host some of the largest informal settlements in the city like Kibra, Mukuru Kwa Njenga, Mathare, and Korogocho. The high population density implies a large population at risk to both flood and heat stress. As a result, the same sub-locations show VHV (Figure 8).

Figure 7: Nairobi city's normalized population density in 2018

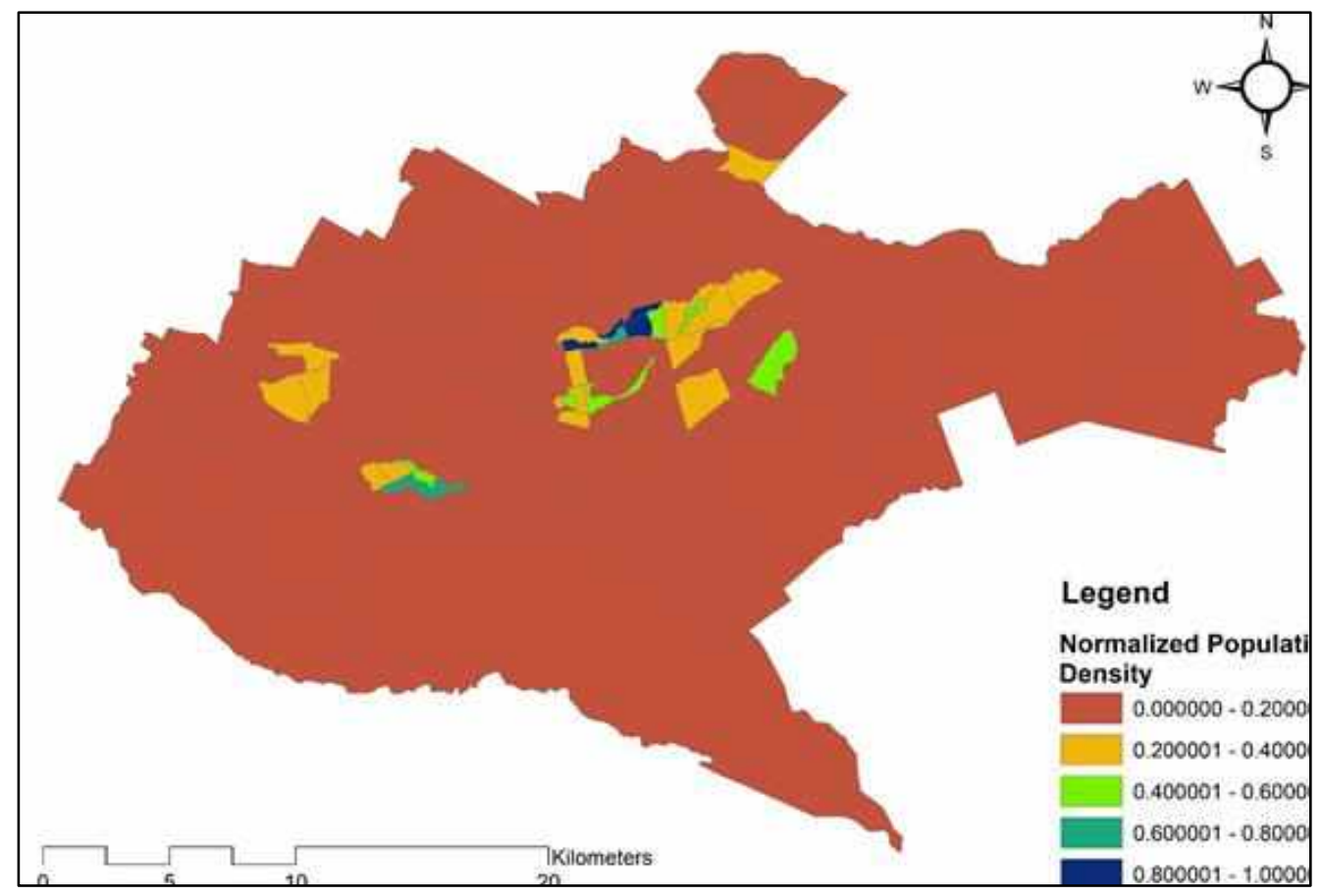

Figure 8: Nairobi city's flood and heat stress vulnerability map based on population density

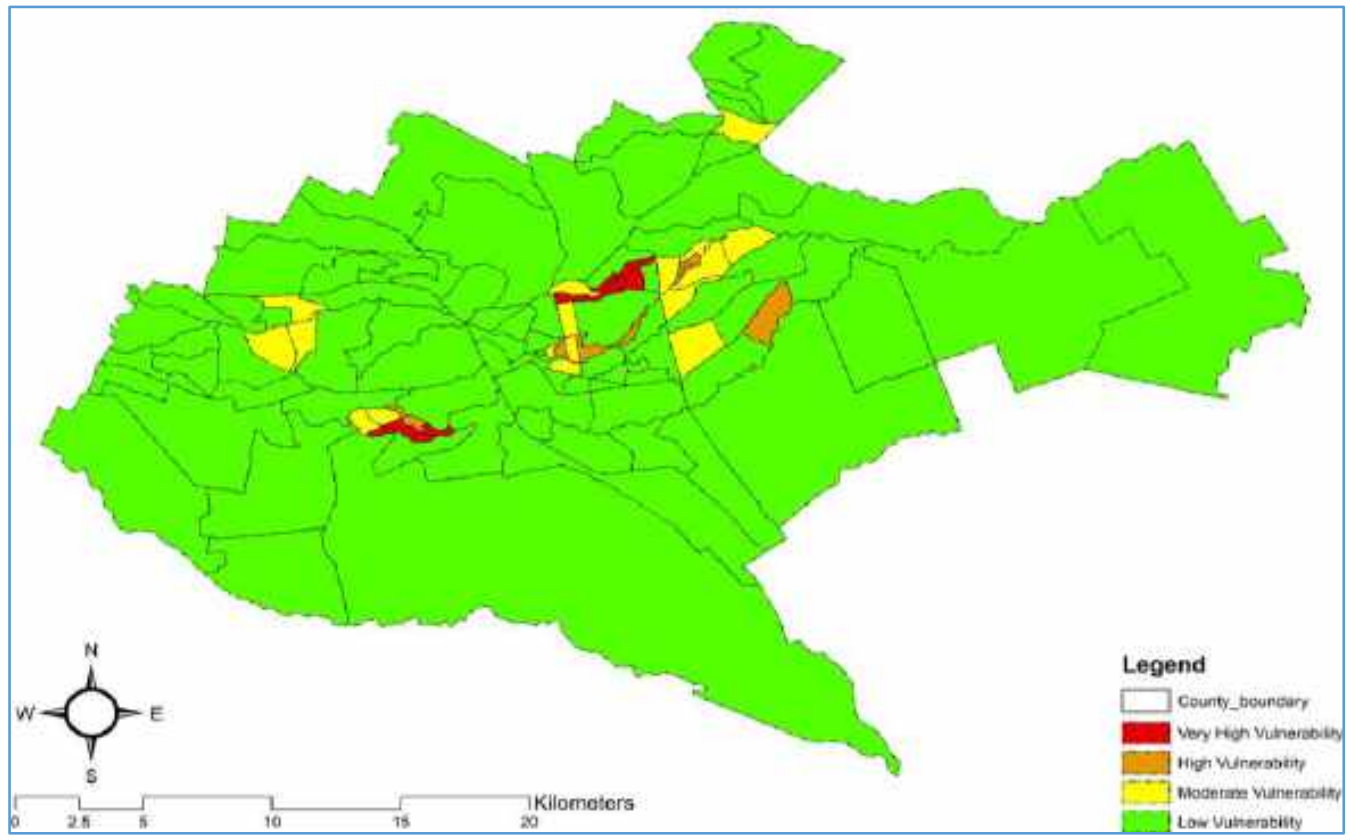




\section{Soil Drainage Properties}

The Soil Mapping of Kenya by ISRIC lists soil drainage properties within Nairobi into 5 classes. They are Well-drained, Imperfectly drained, Poorly drained, Very poorly drained and a non-classified section (Fig. 10). The unclassified, poorly and very poorly drained soils are concentrated along a central horizontal belt. The unclassified zone is a zone of dense development. It is therefore classified among the poorly drained soils due to its imperviousness. This translates into VHV at the centre of the city and LV to the north and west of the city (Fig. 11).

\section{Figure 9: Nairobi city's soil drainage properties}

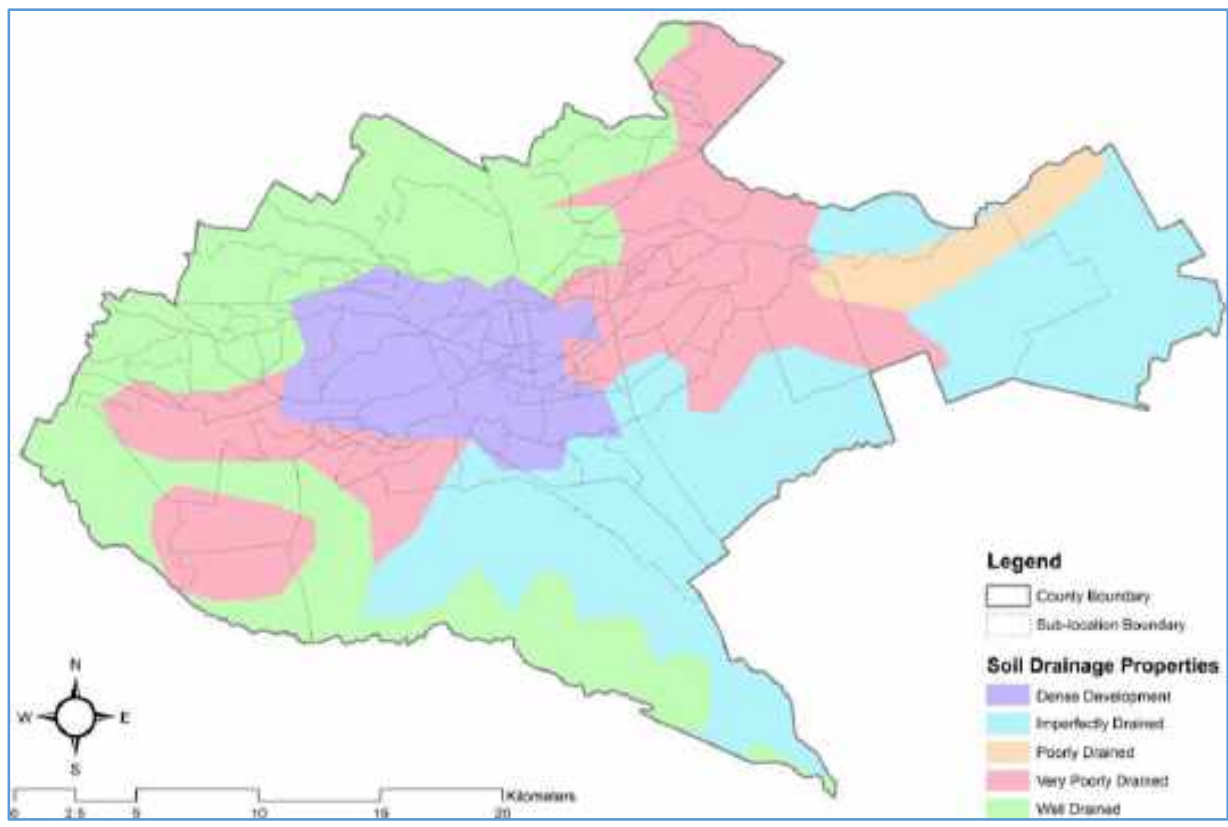

Source: (KALRO)

Figure 10: Nairobi city's flood vulnerability map based on soil drainage properties

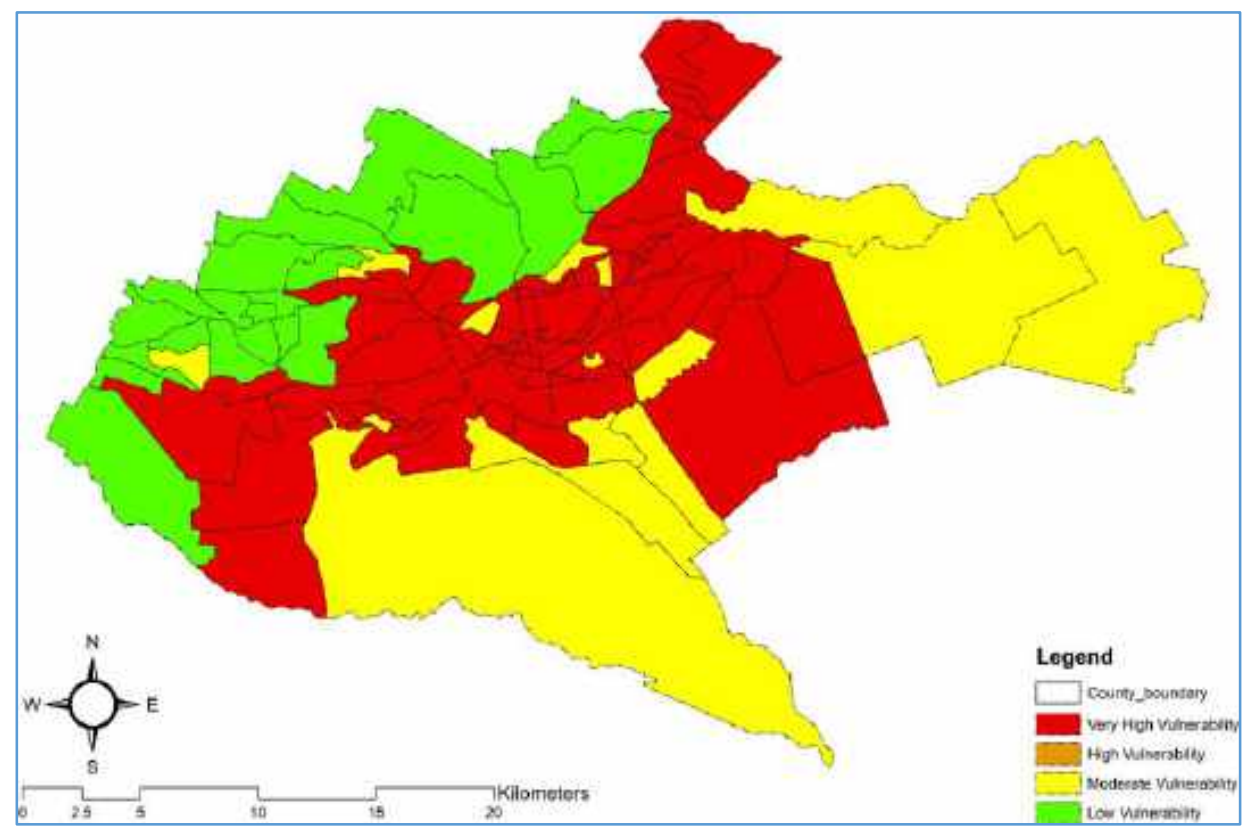


East African Journal of Environment and Natural Resources, Volume 2, Issue 2, 2020

Article DOI: https://doi.org/10.37284/eajenr.2.2.201

\section{Topography}

Majority of the slopes on the eastern side of the city fall below $8 \%$ and the western side above $16 \%$. This translates to an eastern side concentrated MV (Figure 11). $19 \%$ of the sub-locations manifest MV and the rest LV (Figure 12).

Figure 11: Nairobi city's slope analysis

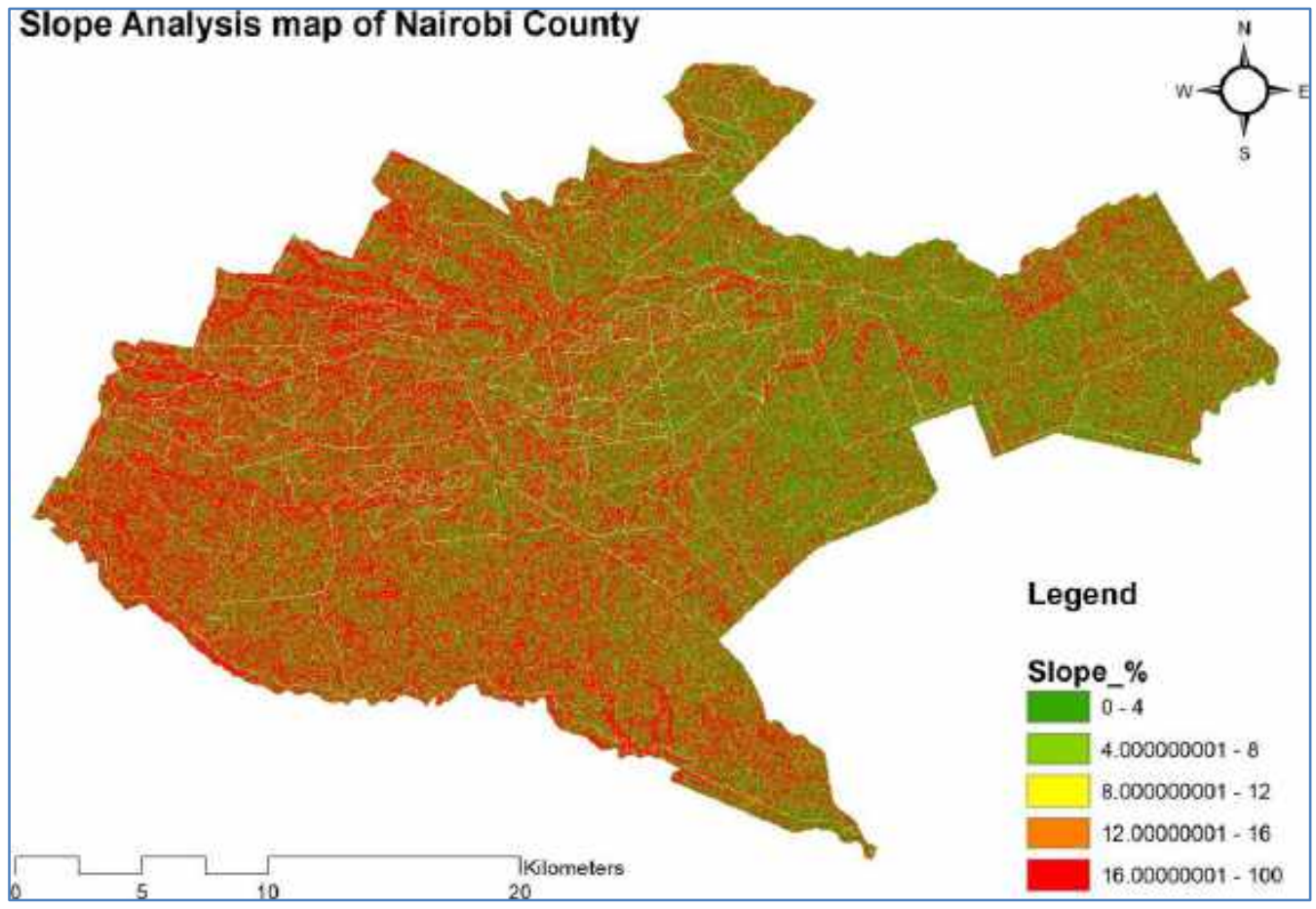

Figure 12: Nairobi city's vulnerability to flooding risk based on slope.

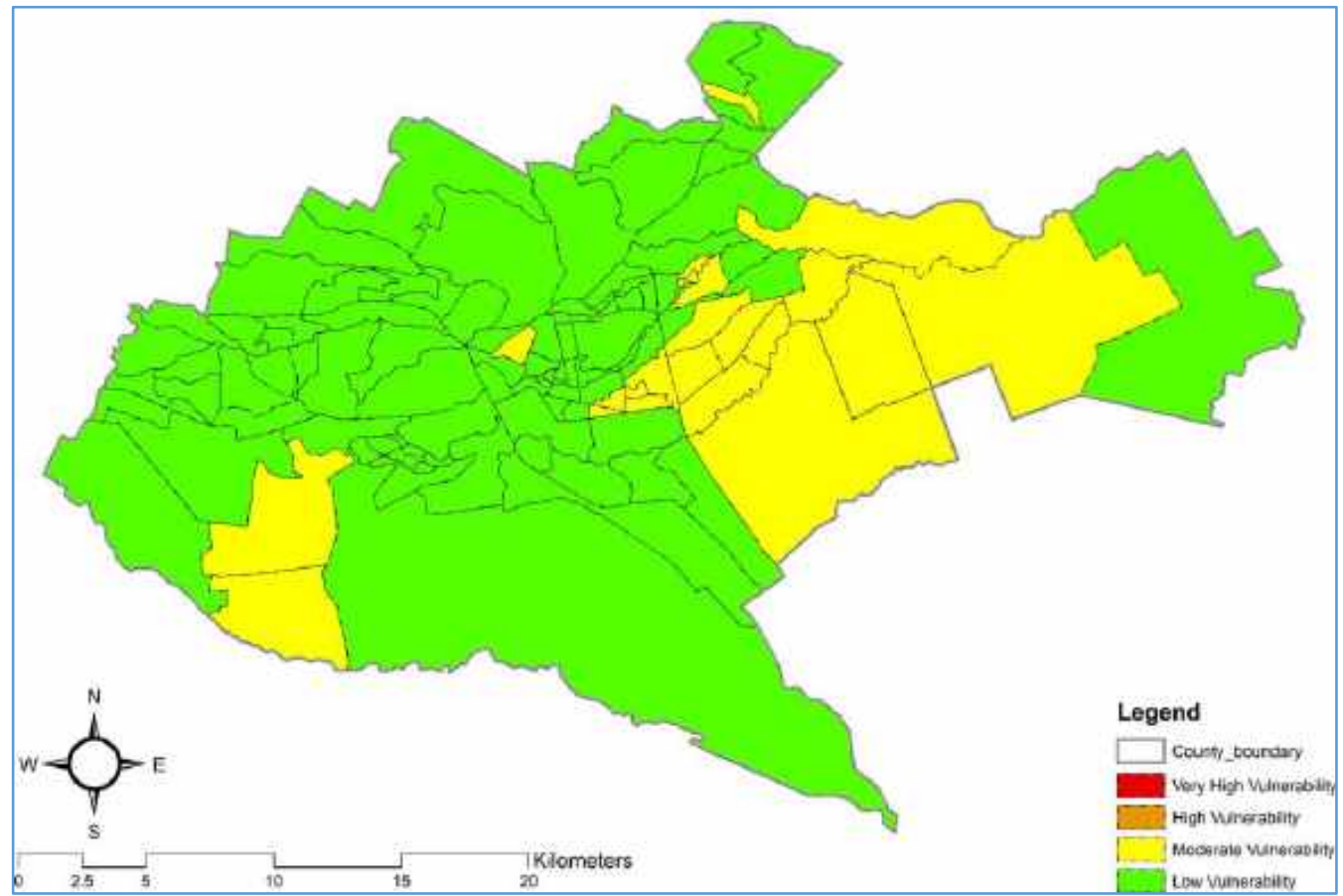




\section{Flow Accumulation}

The flow accumulation considered the flow accumulation model and natural drainage patterns (Figure 13). Those with high flow accumulation connections but no natural drainage pattens were ranked as being moderately vulnerable. MV was selected to account for possible artificial drainage. The MV is concentrated on the central and northern zones of the city (Figure 14).

\section{Figure 13: Nairobi's flow accumulation map}

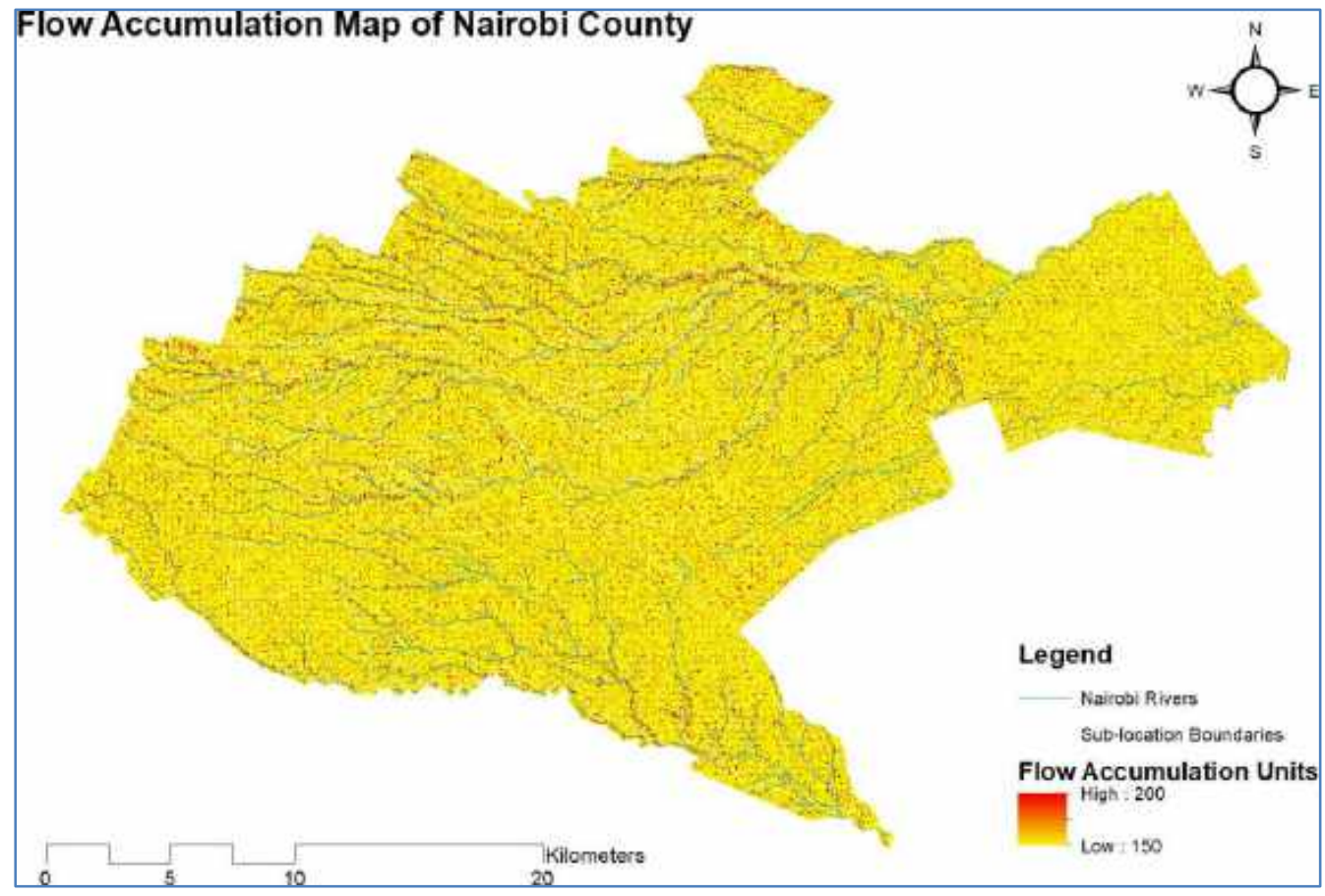

Figure 14: Nairobi's vulnerability to flooding risk based on flow accumulation mapping

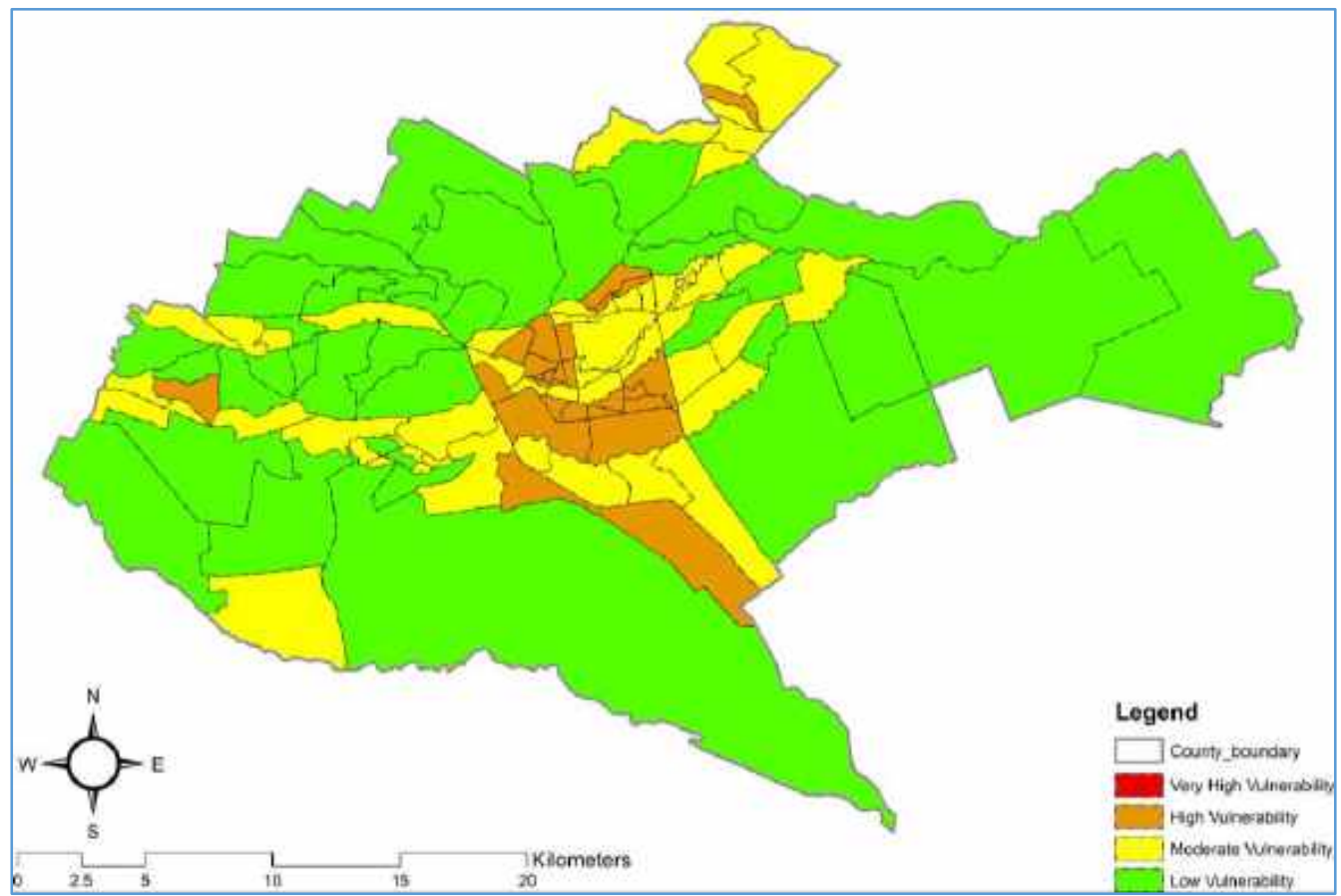




\section{Green Space Network}

The green space network considered two components: open space patterns and the Normalized Differential Vegetation Index (NDVI).
The open space patterns were mapped by the UNHabitat (Figure 15). The central part of the city reveals VHV to HV while the peripheral zones of the city reveal LV (Figure 16).

\section{Figure 15: Nairobi's open spaces}

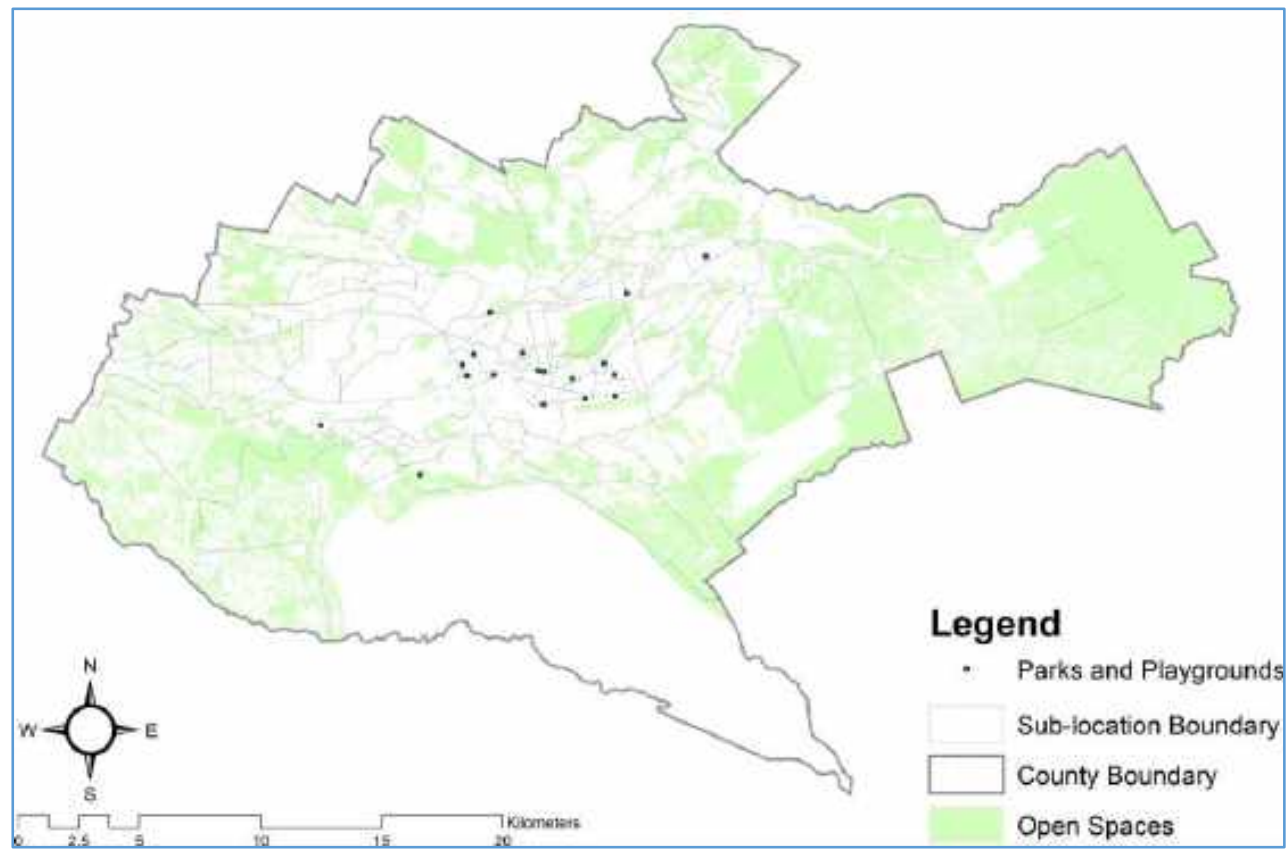

Source (UN-Habitat)

Figure 16: Nairobi's vulnerability to flood and heat stress based on open space networks.

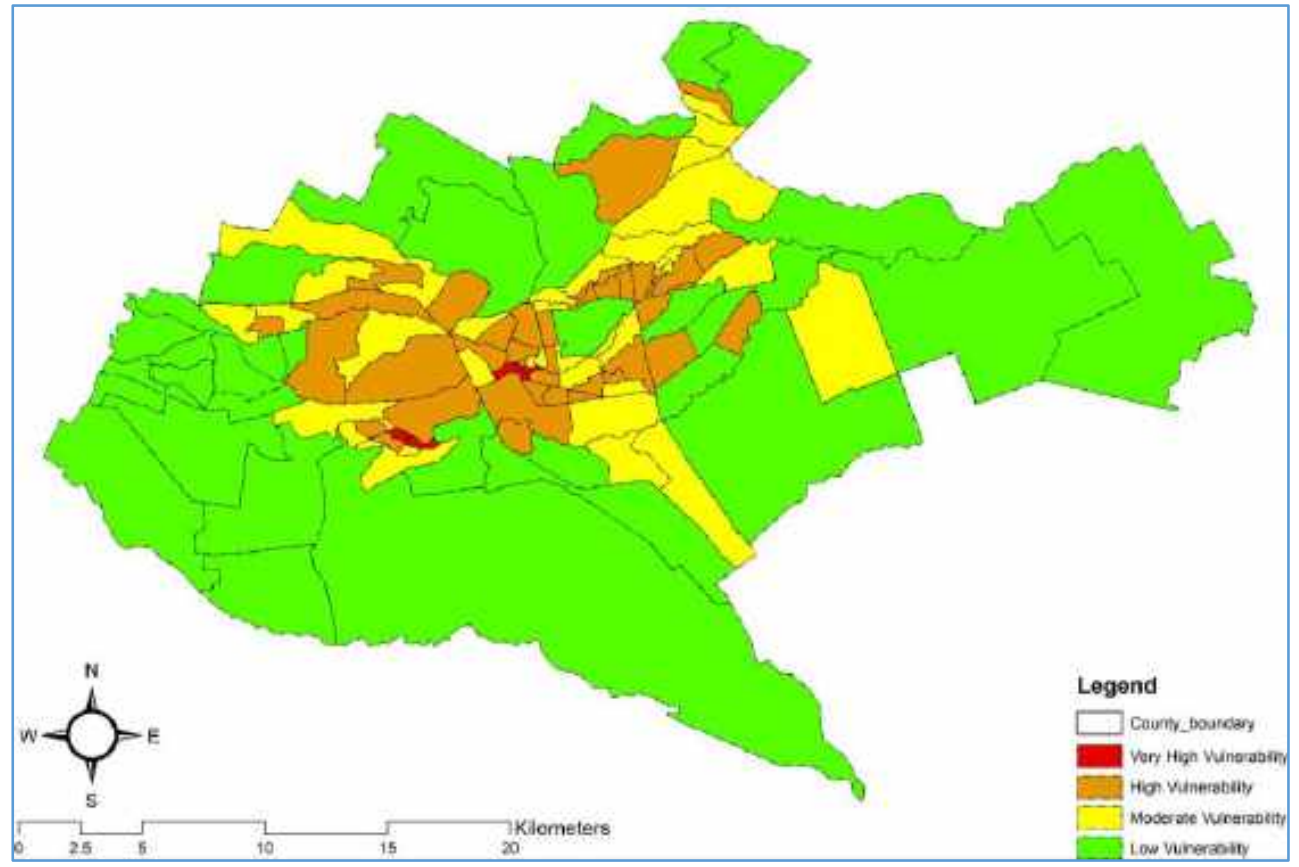


The NDVI model for the year 2018 manifests a western and northwestern concentration of vegetation whose reflective index shows tree cover of good health in the dry season; which is the period Landsat images extracted (Figure 17). Based on this model, the central and eastern zones, and the northern tip of the city display HV compared to the western, northwestern, and southern zones (Figure 18).

\section{Figure 17: Nairobi's NDVI mapping in the dry month of July}

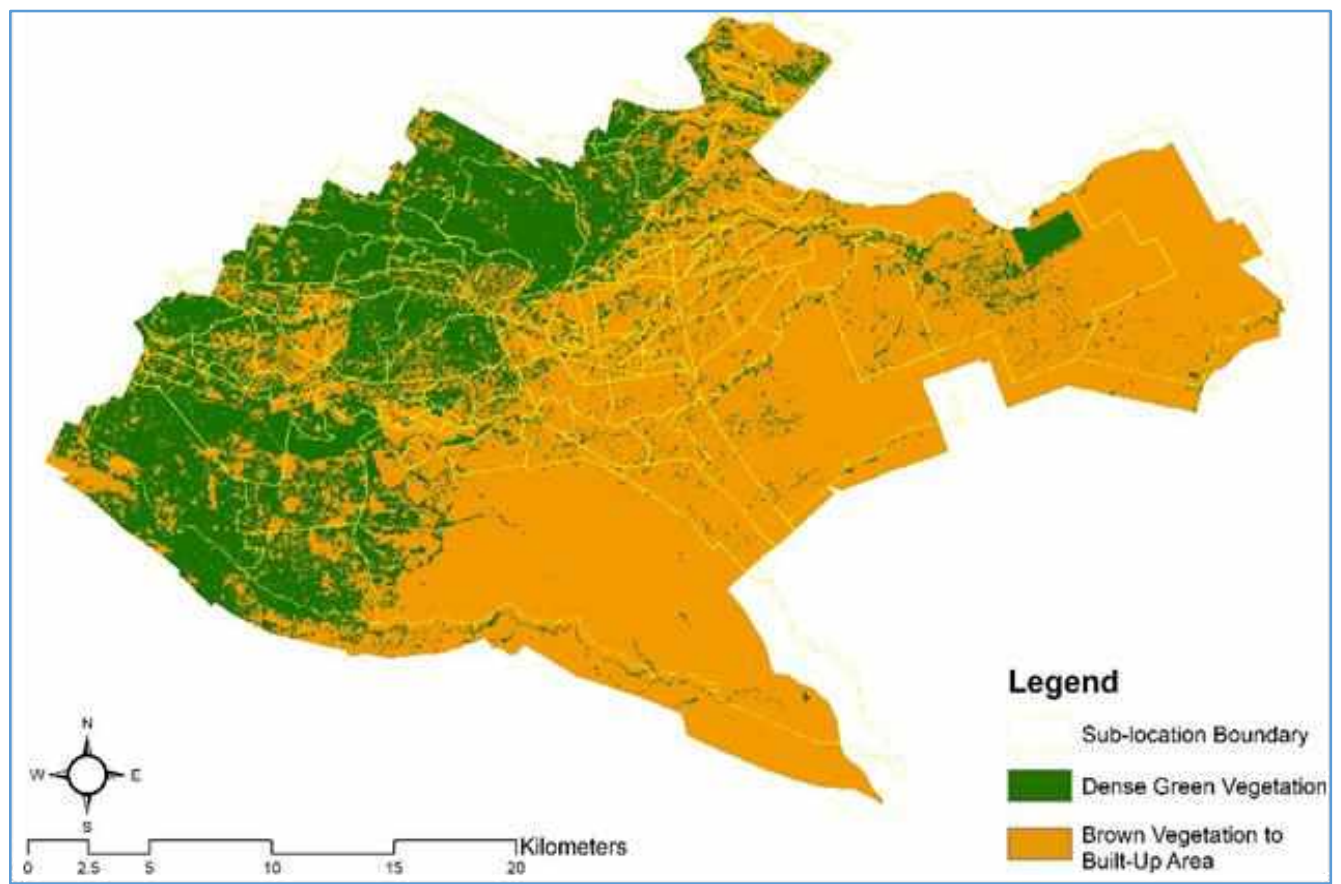

Figure 18: Nairobi's vulnerability to flood and heat stress based on NDVI

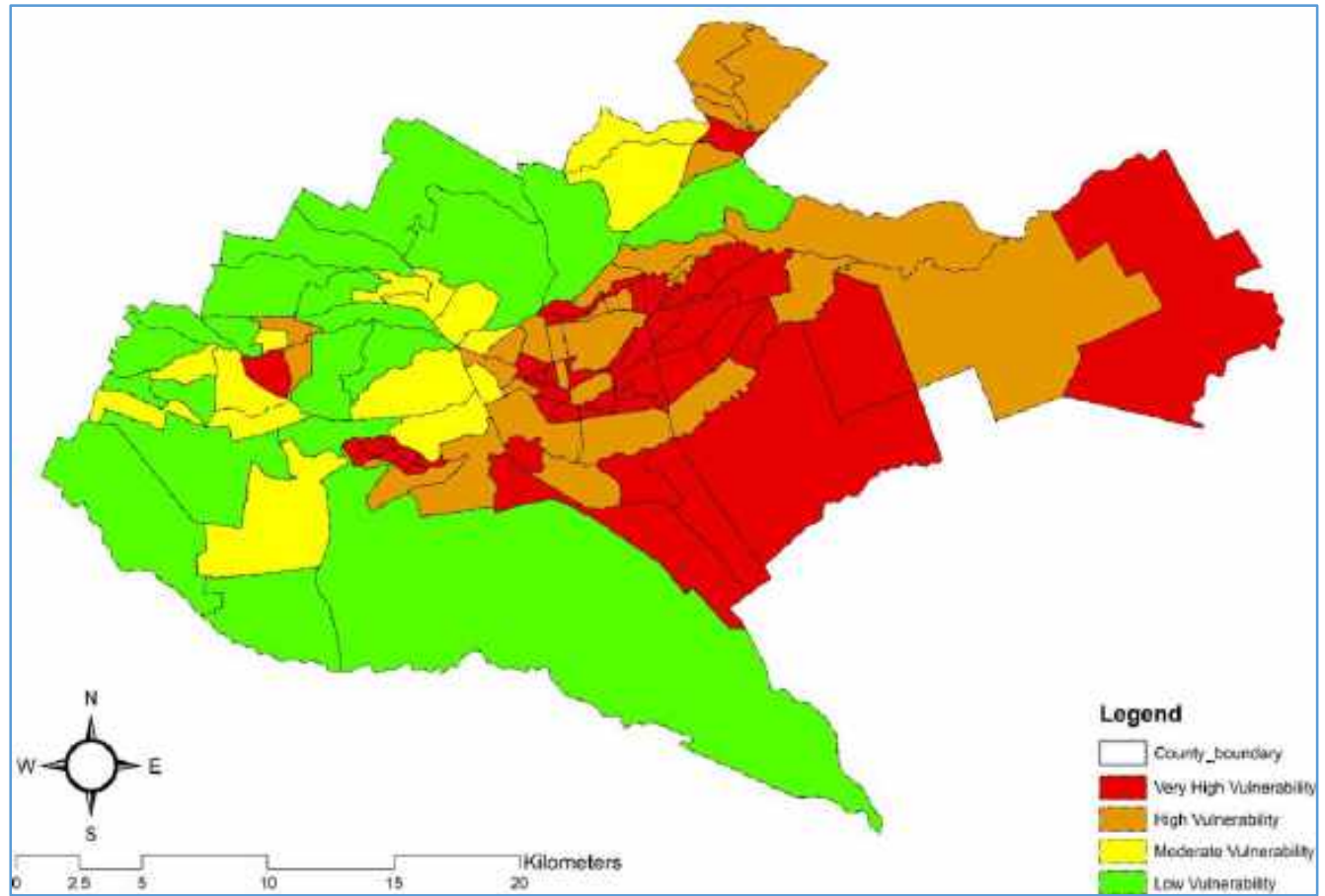


The experts ranked the magnitude of the different parameters in contributing to flood and heat stress vulnerability on the 1-7 Likert scale (Table 4). They ranked in descending order as flow accumulation, land cover, slope and soil drainage properties. Parameters of heat stress in descending order were land cover and NDVI.

Table 4: Expert ranking of different biophysical parameters of Vulnerability in Nairobi City

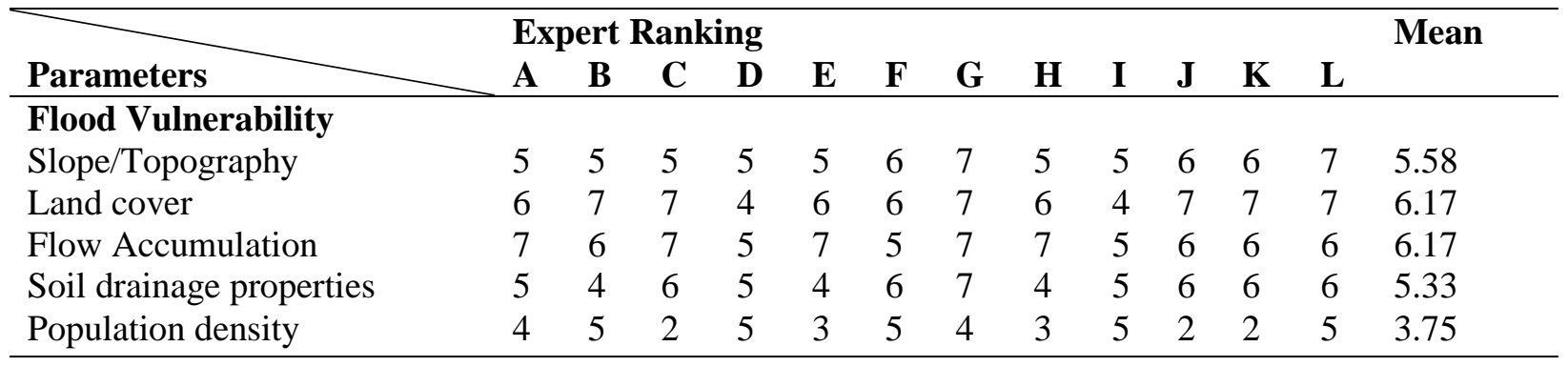

\section{Heat Stress Vulnerability}

Open space network

Land cover

$\begin{array}{lllllllllllll}7 & 6 & 4 & 4 & 3 & 6 & 6 & 3 & 4 & 6 & 6 & 6 & 5.08\end{array}$

Population Density

$\begin{array}{lllllllllllll}6 & 5 & 6 & 4 & 5 & 6 & 5 & 5 & 6 & 6 & 6 & 6 & 5.50\end{array}$

$\begin{array}{lllllllllllll}7 & 5 & 4 & 2 & 4 & 6 & 5 & 4 & 4 & 1 & 3 & 4 & 4.08\end{array}$

Flood vulnerability summary statistics are $40 \mathrm{VHV}$, the central zone with a ring of MV zone around it. $27 \mathrm{HV}, 34 \mathrm{MV}$ and $11 \mathrm{LV}$ sub-locations. Spatially, The LV zones ate to the northern and western sides the VH and HV sub-locations are concentrated in (Figure 19).

Figure 19: Nairobi City County sub-location flood vulnerability map based on biophysical characteristics

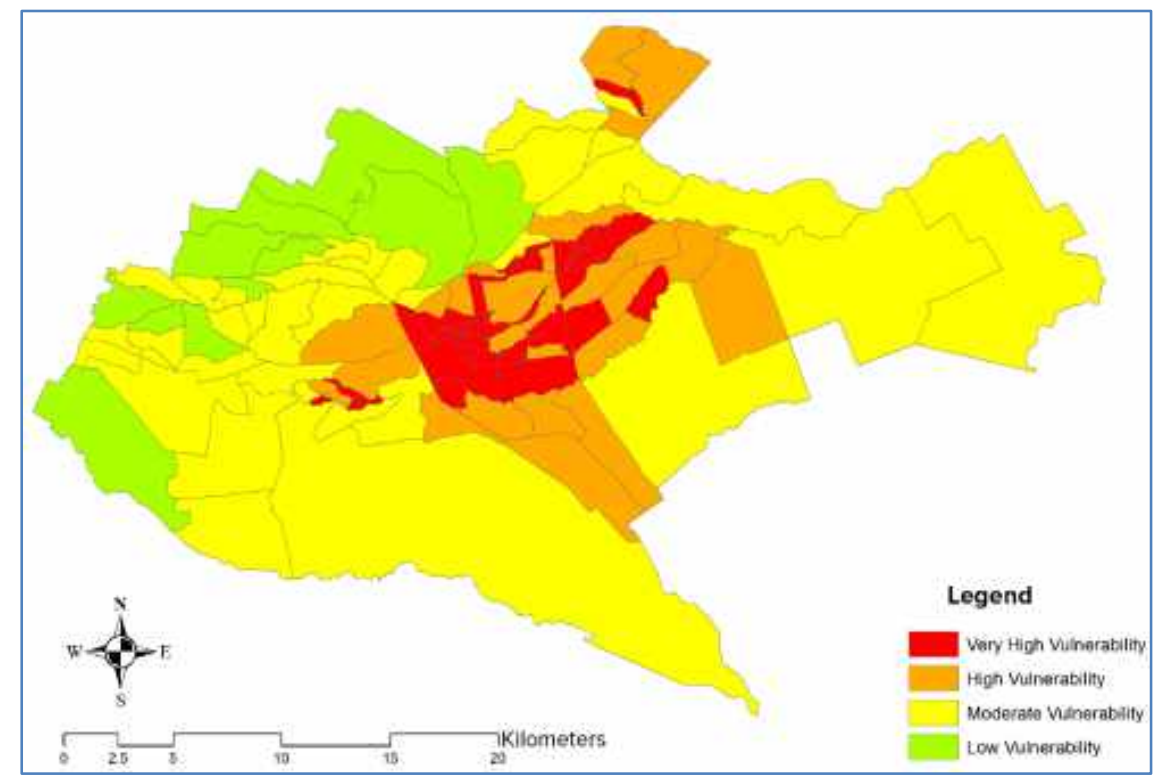

Heat stress vulnerability summary statistics are 27 VHV, $37 \mathrm{HV} 28 \mathrm{MV}$ and $20 \mathrm{LV}$ sub-locations (Figure 20). The MV and LV sublocations are concentrated on the western and northern parts of the city. The $\mathrm{H}$ and VHV sub-locations are in the central and northern zones of the Nairobi. Overall vulnerability summary statistics are $39 \mathrm{VHV}, 39$ HV, $24 \mathrm{MV}$ and $10 \mathrm{LV}$ sub-locations (Figure 21). The VHV is distributed in the central and northern tip of the city. LV area is concentrated in the northern and western side of Nairobi. 
East African Journal of Environment and Natural Resources, Volume 2, Issue 2, 2020

Article DOI: https://doi.org/10.37284/eajenr.2.2.201

Figure 20: Nairobi City County sub-location heat vulnerability map based on biophysical characteristics

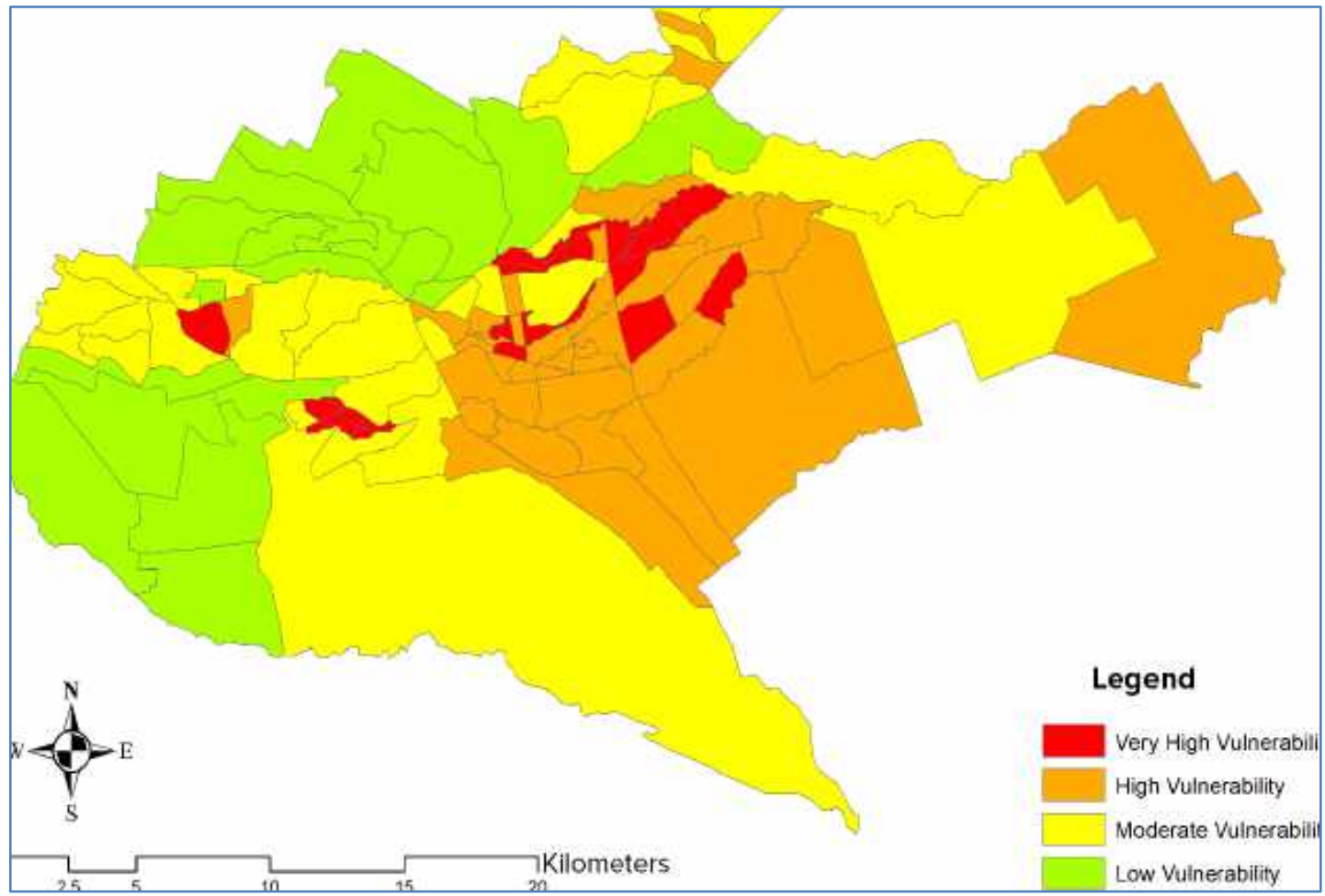

Figure 21: Nairobi's overall vulnerability to a changing climate based on its biophysical characteristics.

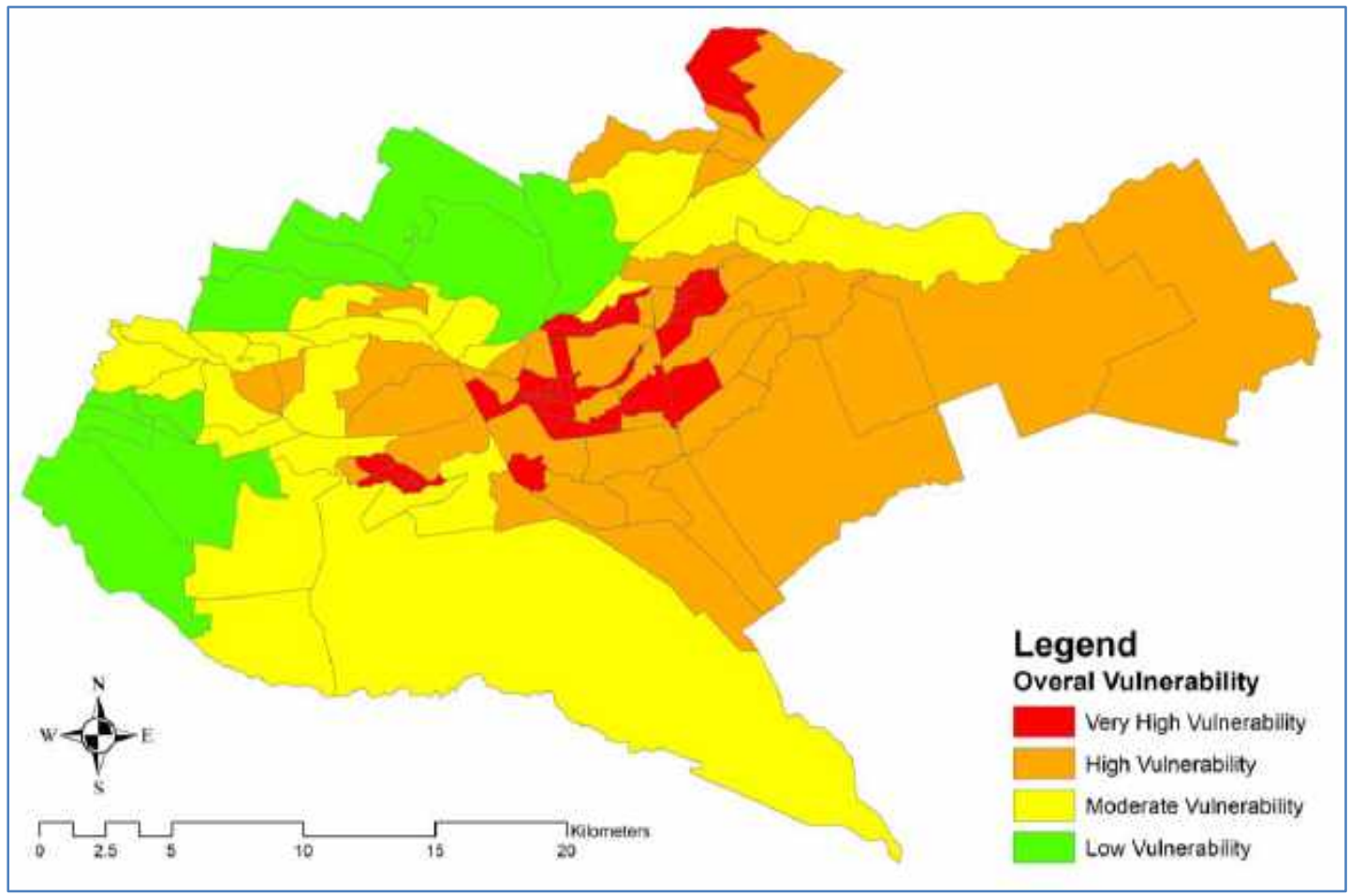




\section{DISCUSSION}

The sub-locations show various levels of vulnerability to the individual biophysical parameters. However, zonal segregation of the different vulnerabilities is clear. For instance, very high and high vulnerability sub-locations are concentrated in the central zone of the city. This changes to moderate vulnerability spreading to the east and south with a narrow belt extending westwards. However, the northern and western sublocations reveal low vulnerability.

This zonal vulnerability compares with the documented historical segregated approach to the city's planning. The eastern side of the city was low-income African neighbourhoods and the northern and western sides of the city were high income, low-density white settlements. This segregation has played a significant role in increasing the city's biophysical vulnerability in a changing climate. Informal settlements and formal low-income sub-locations like Korogocho, Kibra, Huruma, Laini Saba, Mathare, and Lindi manifest top levels of vulnerability to biophysical characteristics. This emanates from the very high population density that exposes the residents to climate risks in two aspects. First is the high population that becomes vulnerable in case of hazards such as flooding. Second is the high densities that translate to high urban heat island and surface sealing that increase heat and flood vulnerability, respectively. This is at pace with the poorly drained soils that increase runoff and lack of adequate tree cover to improve local temperatures.

High-income sub-locations like Karen, Hardy, Garden, Kyuna, and Muthaiga manifests low biophysical vulnerability because of the low density of built-up areas and large swathes of open and green spaces that provide resilience attributes such as temperature regulation and percolation of stormwater. The neighbourhoods also have welldrained soils and slopes above $16 \%$ both of which ensure good drainage of stormwater.

\section{CONCLUSION AND RECOMMENDATION}

These findings support the argument by Satterthwaite, Huq, Pelling, Reid, \& Lankao (2007) who classify the urban poor high among the vulnerable urban populations that require urgent action. Similarly, the multifaceted nature of their vulnerability as discussed by Carmin \& Zhang (2009) is evidence in Nairobi where the urban poor inhabit locations at risk due to multiple parameters such as soil drainage properties, slopes percentages, and landcover types. Therefore, to achieve urban climate resilience, urban planning and development in Nairobi must be sensitive to biophysical parameters like the nature and distribution of open spaces, types of vegetation, soil types and density of development, especially in the informal and lowincome neighbourhoods (Figure 22).

Figure 22: Sample adaptation approaches in high-density neighbourhoods and informal settlements in Kibra sub-location

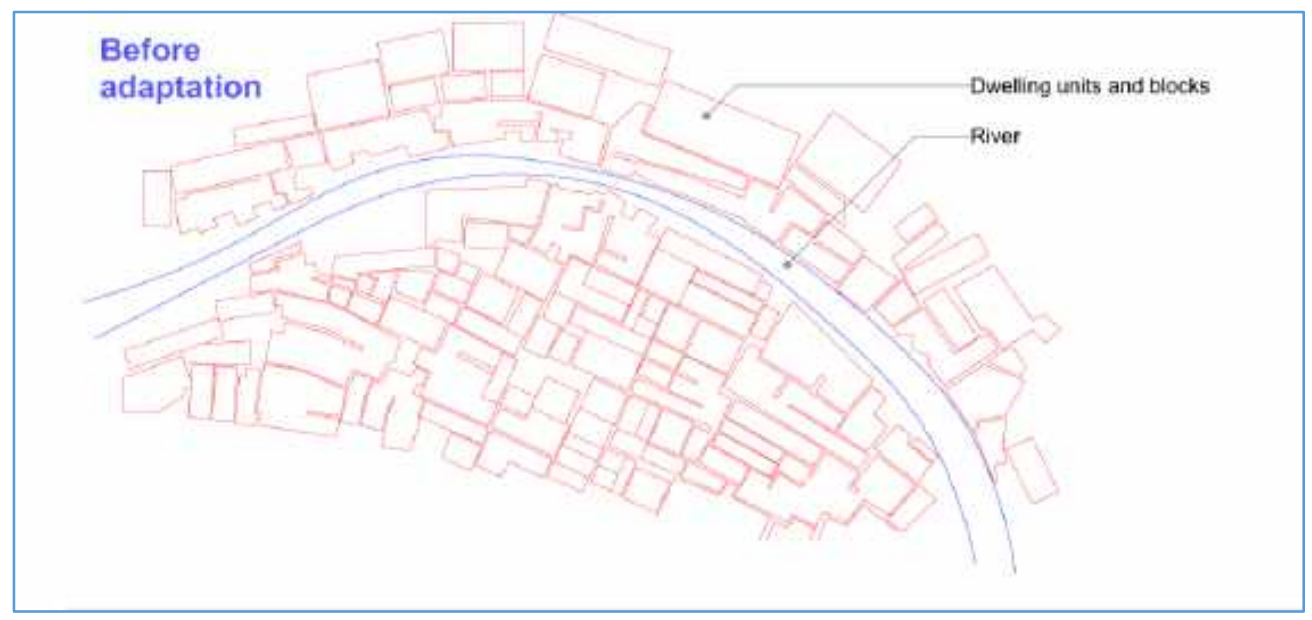




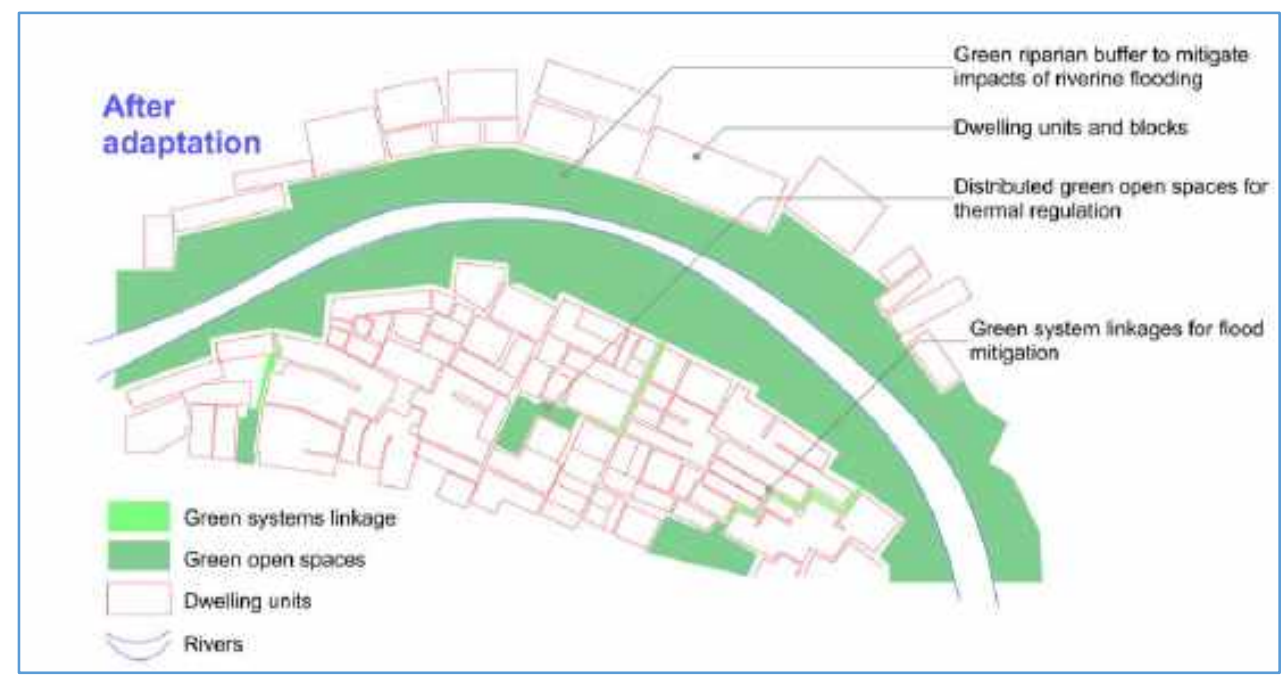

Development of new neighbourhoods, urban renewal and regeneration projects such as the proposed Eastlands Urban Renewal Project must consider biophysical characteristics and their role in climate change resilience. For instance, the highdensity development can be concentrated in the poorly drained soils and the green open spaces located on the well-drained deep soils. This would aid in the proper management of stormwater runoff.

Some of the ecosystem-based adaptation approaches such as river re-naturalization, green infrastructure and green corridors proposed by
Geneletti \& Zardo (2016) and Scarano (2017) are ideal for application in Nairobi city as they deal with both biophysical and socio-economic aspects. Their downscaled implementation can include decentralization of smaller green spaces in highdensity sub-locations such as Umoja and Kibra, redesign of road medians for water management, re-specification of street vegetation species to incorporate a mix of deciduous and evergreen trees and the incorporation of eco-roofs and walls in high-density developments like the Central Business District (Figure 23).

\section{Figure 23: Climate change adaptation within a section of the Nairobi CBD}

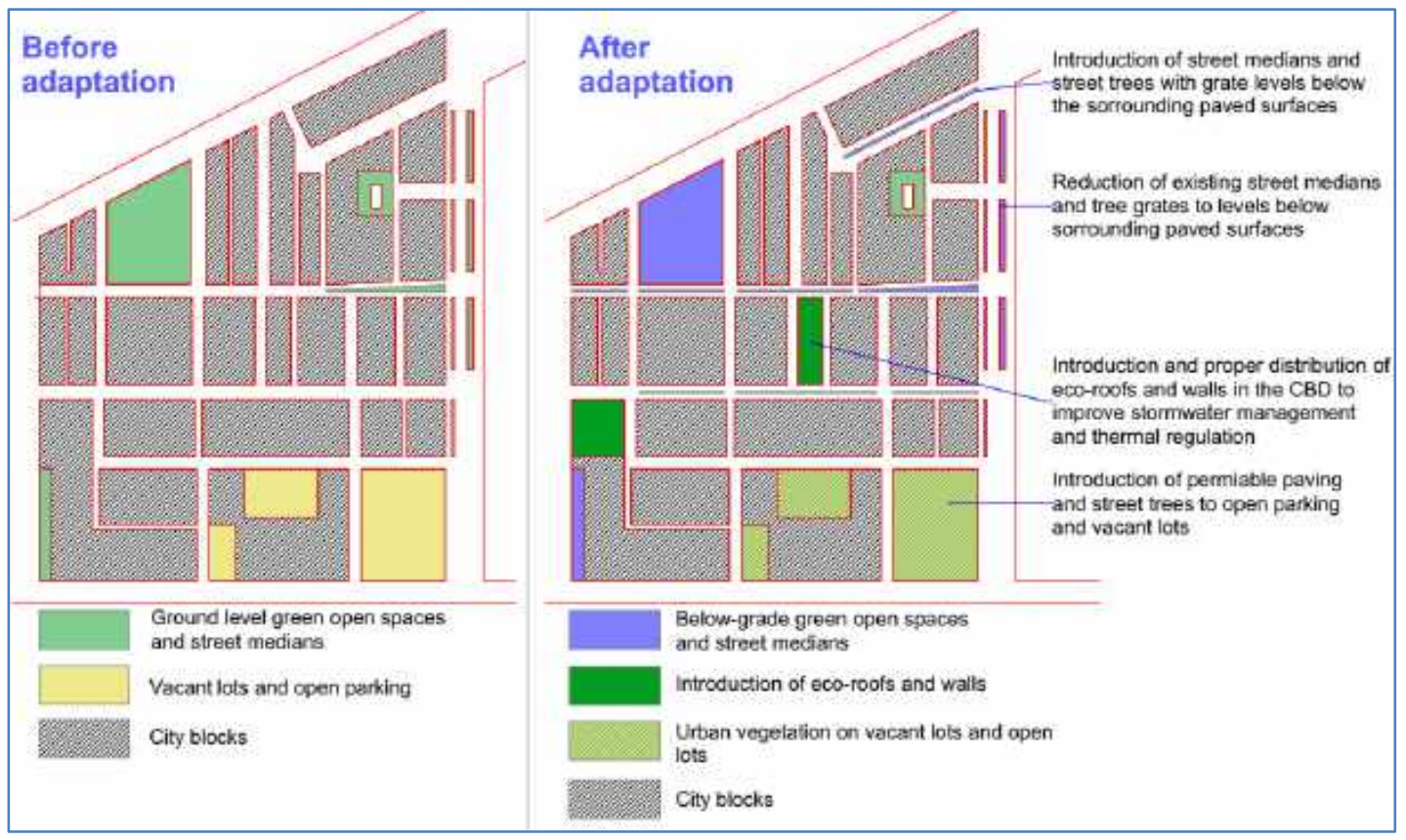


Further studies on biophysical vulnerability in Nairobi City should incorporate the parameters of dwelling types and materials.

\section{REFERENCES}

Apreda, C., D'Ambrosio, V., \& Di Martino, F. (2019). A Climate Vulnerability and Impact Assessment Model for Complex Urban Systems. Environmental Science and Policy, 93, 11-26.

Bao, J., Li, X., \& Yu, C. (2015). The Construction and Validation of the Heat Vulnerability Index, a Review. International Journal of Environmental Research and Public Health, $12,7220-7234$.

Barron, L., Ruggieri, D., \& Branas, C. (2018). Assessing Vulnerability to Heat: A Geospatial Analysis for the City of Philadelphia. Urban Science, 2(38).

Bathrellos, G. D., Karymbalis, E., Skilodimou, H. D., Gaki-Papanastassiou, K., \& Baltas, E. A. (2016). Urban Hazard Flood Assessment in the Basin of Athens Metropolitan City, Greece. Environmental Earth Science, 75(319).

Carmin, J., \& Zhang, Y. (2009). Achieving urban climate adaptation in Europe and Central Asia. The World Bank.

Chen, H., Ito, Y., Sawamukai, M., \& Tokunaga, T. (2015). Flood Hazard Assessment in the Kujukuri Plain of Chiba Prefecture, Japan, Based on GIS and Multicriteria Decision Analysis. Natural Hazard, 78(1), 105-120.

Dong, W., Liu, Z., Zhang, L., Tang, Q., Liao, H., \& Li, X. (2014). Assessing Heat Health Risk for Sustainability in Beijing's Urban Heat Island. Sustainability, 6, 7334-7357.

Dou, X., Song, J., Wang, L., Tang, B., Xu, S., Kong, F., \& Jiamg, X. (2017). Flood Risk Assessment and Mapping based on a Modified Multi-parameter Flood Hazard Index Model in the Guanzhong Urban Area, China. Stochastic Environment Research and Risk Assessment, 32(4), 1131-1146.
Doyle, C., Sullivan, J., Mahtta, R., \& Pandey, B. (2017). Assessing Biophysical and Social Vulnerability to Natural Hazards in Uttarakhand, India. Washington, DC: World Bank.

Elkhrachy, I. (2015). Flash Flood Hazard Mapping Using Satellite Images and GIS Tools: A Case Study of Najran City, Kingdom of Saudi Arabia (KSA). The Egyptian Journal of Remote Sensing and Space Sciences, 18(2), 261-278.

Elmoustafa, A. M. (2012). Weighted normalized risk factor for floods risk assessment. Ain Shams Engineering Journal, 3(4), 327-332.

Field, C. B., Barros, V., Stocker, T. F., \& Dahe, Q. (2012). Managing the risks of extreme events and disasters to advance climate change adaptation: special report of the intergovernmental panel on climate change. Cambridge University Press.

Fritzsche, K., Schneiderbauer, S., Bubeck, P., Stefan, K., Buth, M., Zebisch, M., \& Kahlenborn, W. (2014). The Vulnerability Sourcebook: Concept and guidelines for standardised vulnerability assessments. Bonn and Eschborn: GIZ.

Gamble, J. L., Schmeltz, M., Hurley, B., Hsieh, J., Jette, G., \& Wagner, H. (2018). Mapping the Vulnerability of Human Health to Extreme Heat in the United States. Washington, DC: EPA.

Geneletti, D., \& Zardo, L. (2016). Ecosystembased adaptation in cities: An analysis of European urban climate adaptation plans. Land Use Policy, 50, 38-47.

Gigovich, L., Pamvear, D., Bajic, Z., \& Drobnjak, S. (2017). Application of GIS-internal Rough AHP Methodology for Flood Hazard Mapping in Urban Areas. Water, 9(360), 1-26.

Gill, S. E., Handley, J. F., Ennos, A. R., \& Pauliet, S. (2007). Adapting Cities for Climate Change: The role of Green Infrastructure. Built Environment, 33(1), 115-133.

Huang, J., Kang, Q., Yang, J. X., \& Jin, P. W. (2017). Multifactor analysis and simulation of 
the surface runoff and soil infiltration at different slope gradients. IOP Conference Series: Earth and Environmental Science, 82(1), 12019. IOP Publishing.

Inostroza, L., Palme, M., \& de la Barrera, F. (2016). A heat vulnerability index: spatial patterns of exposure, sensitivity and adaptive capacity for Santiago de Chile. PLOS One, 11(9), e0162464.

Intergovernmental Panel on Climate Change (IPCC). (2014). Climate Change 2014: Impacts, Adaptation, and Vulnerability. Part A: Global and Sectoral Aspects. Contribution of Working Group II to the Fifth Assessment Report of the Intergovernmental Panel on Climate Change [Field, C.B., V.R. Barros, D.J. Dokken, K.J. Mach, M.D. Mastrandrea, T.E. Bilir, M. Chatterjee, K.L. Ebi, Y.O. Estrada, R.C. Genova, B. Girma, E.S. Kissel, A.N. Levy, S. MacCracken, P.R. Mastrandrea, and L.L.White (eds.)]. Cambridge, United Kingdom and New York, NY, USA: Cambridge University Press.

Jänicke, B., Holtmann, A., Kim, K. R., Kang, M., Fehrenbach, U., \& Scherer, D. (2019). Quantification and evaluation of intra-urban heat-stress variability in Seoul, Korea. International journal of biometeorology, 63(1), 1-12.

JICA. (2004). The Project on Integrated Urban Development Master Plan for the City of Nairobi in the Republic of Kenya. Tokyo.

Kenya National Bureau of Statistics. (2010). Kenya Population and Housing Census 2009. Nairobi: Government Printer.

Kenya National Bureau of Statistics. (2019). 2019 Kenya population and housing census. Volume 1: Population by county and sub-county. Nairobi.

Krellenberg, K., Welz, J., Link, F., \& Barth, K. (2017). Urban vulnerability and the contribution of socio-environmental fragmentation. Progress in Human Geography, 41(4), 408-431.
Macintyre, H. L., Haviside, C., Taylor, J., Picetti, R., Symonds, P., Cai, X. M., \& Vardoulakis, S. (2018). Assessing Urban Population Vulnerability and Environmental Risk Across an Urban Area During Heatwaves Implications for Health Protection. Science of the Total Environment, 610, 678-690.

McCarthy, J. J., Canziani, O. F., Leary, N. A., Dokken, D. J., \& White, K. S. (2001). Climate change 2001: impacts, adaptation, and vulnerability: contribution of Working Group II to the third assessment report of the Intergovernmental Panel on Climate Change (Vol. 2). Cambridge University Press.

Méndez-Lázaro, P., Muller-Karger, F. E., Otis, D., McCarthy, M. J., \& Rodríguez, E. (2018). A heat vulnerability index to improve urban public health management in San Juan, Puerto Rico. International journal of biometeorology, 62(5), 709-722.

Mentzafou, A., Markgianni, V., \& Dimitriou, E. (2017). The Use of Geospatial Technologies in Flood Hazard Mapping and Assessment: Case Study from River Evros. Pure Applied Geophysics, 174(2), 679-700.

Mentzafou, A., Markogianni, V., \& Dimitriou, E. (2018). The use of geospatial technologies in flood hazard mapping and assessment: case paper from River Evros. In Geoinformatics and Atmospheric Science (pp. 221-242). Springer.

Nassif, S. H., \& Wilson, E. M. (1975). The influence of slope and rain intensity on runoff and infiltration/l'influence de l'inclinaison de terrain et de l'intensité de pluie sur l'écoulement et l'infiltration. Hydrological Sciences Journal, 20(4), 539-553.

Nayak, S. G., Shrestha, S., Kinney, P. L., Ross, Z., Sheridan, S. C., Pantea, C. I., .. . Hwang, S. A. (2018). Development of a heat vulnerability index for New York State. Public Health, 161, 127-137.

Oke, T. R., Mills, G., Christen, A., \& Voogt, J. A. (2017). Urban climates. Cambridge University Press. 
Ouma, Y. O. \& Tateishi, R. (2014). Urban Flood Vulnerability and Risk Mapping Using Integrated Multi-Parametric AHP and GIS: Methodological Overview and Case Study Assessment. Water, 16, 1515-1545.

Pattacini, L. (2012). Climate and Urban Form. Urban Design International, 17(2), 106-114.

Perry, M., Canziani, O., Palutikof, J., Linden, P. V. D., \& Hanson, C. (2007). Climate Change 2007: Impacts, Adaptation and Vulnerability: Contribution of Working Group II to the Fourth Assessment Report of the Intergovernmental Panel on Climate Change. Cambridge University Press for the Intergovernmental Panel on Climate Change.

Pincetl, S., Chester, M., \& Eisenman, D. (2016). Urban Heat Stress Vulnerability in the U.S. Southwest: The Role of Sociotechnical Systems. Sustainability, 8(842).

Reid, C. E., O'Neill, M. S., Gronlund, C. J., Brines, S. J., Brown, D. G., Diez-Roux, A. V., \& Schwartz, J. (2009). Mapping Community Determinants of Heat Vulnerability. Environmental Health Perspectives, 117(11), 1730-1736.

Romero-Lankao, P., Qin, H., \& Dickinson, K. (2012). Urban vulnerability to temperaturerelated hazards: A meta-analysis and metaknowledge approach. Global Environmental Change, 22(3), 670-683.

Satapathy, S., Porsche, I., Rolker, D., Bhatt, S., Tomar, S., \& Nair, S. (Eds.). (2014). A Framework for Climate Change Vulnerability Assessments. New Delhi: GIZ \& CCA RAI.

Sattethwaite, D., Huq, S., Reid, H., Pelling, M., \& Lankao, P. R. (2009). Adapting to Climate Change in Urban Areas: The possibilities and constraints in low and middle-income Nations. In J. Bicknell, D. Dodman, \& D. Satterthwaite (Eds.), Adapting Cities to Climate Change: Understanding and Addressing the development challenges (pp. 3-34). London: Earthscan.
Savić, S., Marković, V., Šećerov, I., Pavić, D., Arsenović, D., Milošević, D., ... \& Pantelić, M. (2018). Heatwave risk assessment and mapping in urban areas: case study for a midsized Central European city, Novi Sad (Serbia). Natural hazards, 91(3), 891-911.

Scarano, F. R. (2017). Ecosystem-based adaptation to climate change: concept, scalability and a role for conservation science. Perspectives in Ecology and Conservation, 15(2), 65-73.

Skilodimou, H. D., Bathrellos, G. D., Chousianitis, K., Youssef, A. M., \& Pradhan, B. (2019). Multi-hazard Assessment Modeling via Multicriteria Analysis and GIS: A Case Study. Environmental Earth Sciences, 78(2), 7.

Stangl, P. (2018). Prospects for Urban Morphology in Resilience Assessment. In Y. Yamagata, \& A. Sharifi (Eds.), ResilienceOriented Urban Planning, Lecture Notes in Energy 65 (pp. 181-193). Cham: Springer International Publishing AG.

Stefanidis, S., \& Stathis, D. (2013). Assessment of Flood Hazard based on Natural and Anthropogenic Factors Using Analytic Hierarchy Process (AHP). Natural Hazards, 68, 569-585.

Swanson, D., Hiley, J., \& Venema, H. D. (2007). Indicators of adaptive capacity to climate change for agriculture in the prairie region of agriculture: An analysis based on Statistics Canada's Census of Agriculture. IISD Draft Working Paper for Adaptation as Resilience Building.

Swart, R., Fons, J., Geertsema, W., van Hove, B., Gregor, M., Havranek, M., . . . Peltonen, L. (2012). Urban Vulnerability Indicators: A joint report of ETC-CCA and ETC-SIA. Copenhagen: EEA.

Thomas, V., \& López, R. (2015). Global increase in climate-related disasters. Asian Development Bank Economics Working Paper Series, No. 466. Manila: Asian Development Bank (ADB). 
UNHabitat. (2016). Community-Led, Citywide Open Public Spaces Inventory and Analysis. Nairobi: UNHabitat.

United Nations Department of Economic and Social Affairs. (2018). 2018 Revision of World Urbanization Prospects. Retrieved December 26, 2019, from https://www.un.org/development/desa/publicat ions/2018-revision-of-world-urbanizationprospects.html

United Nations Framework Convention on Climate Change (UNFCCC). (2011). Fact sheet: Climate change science - the status of climate change science today. Retrieved from https://unfccc.int/files/press/backgrounders/ap plication/pdf/press_factsh_science.pdf

University of Nairobi. (2018). Engineering Properties of Soils Case Paper: Nairobi Area. Retrieved from University of Nairobi: Department of Geology website: http://geology.uonbi.ac.ke/node/1949

Weber, S., Sadoff, N., Zell, E., \& de Sherbinin, A. (2015). Policy-relevant Indicators of Mapping the Vulnerability of Urban Populations to Extreme Heat Events: A Case Study of Philadelphia. Applied Geography, 63, 231-243.

Wilhelmi, O. V., \& Hayden, M. H. (2010). Connecting people and place: a new framework for reducing urban vulnerability to extreme heat. Environmental Research Letters, 5(1), 014021.

Wolf, T., \& McGregor, G. (2013). The development of a heat wave vulnerability index for London, United Kingdom. Weather and Climate Extremes, 1, 59-68.

World Meteorological Organization (WMO). (2019). Global Climate in 2015-2019: Climate change accelerates | World Meteorological Organization. Retrieved December 26, 2019, from https://public.wmo.int/en/media/pressrelease/global-climate-2015-2019-climatechange-accelerates. 